\title{
Expanding the Exploration of Civil Law in New France, beyond Quebec to Acadie: 1608-1867
}

\author{
C. Mark Macneill \\ University of Ottawa, Ottawa, Ontario, Canada \\ Email: macneillmark@hotmail.com
}

How to cite this paper: Macneill, C. M. (2021). Expanding the Exploration of Civil Law in New France, beyond Quebec to Acadie: 1608-1867. Beijing Law Review, 12, 1215-1251.

https://doi.org/10.4236/blr.2021.124063

Received: October 22, 2021

Accepted: December 17, 2021

Published: December 20, 202

Copyright $\odot 2021$ by author(s) and Scientific Research Publishing Inc. This work is licensed under the Creative Commons Attribution International License (CC BY 4.0).

http://creativecommons.org/licenses/by/4.0/ (c) (i) Open Access

\begin{abstract}
This study was completed in partial fulfillment of coursework in Civil Law Reasoning within the University of Ottawa, Faculty of Civil Law, Licentiate in Law, National Program. Obligations are also due to the paper sponsorship by the Cape Breton Island Foundation (CBIF) Incorporated, which is an independent, non-partisan public policy think tank focused on governance impacts on Cape Breton Island. In exploring Civil Law's origin and evolution within New France, leading up to the creation of Quebec and the preservation of French Civil Law, this paper seeks to explore the status and operation of civil law in the rest of Canada's New France territory which we know as Atlantic Canada today, and was formerly known as Acadie. Focus will be paid to Cape Breton Island (Isle Cap Breton), also formerly known as Isle Royale and which twice was part of New France with French Colonial status, and twice was defeated by British (and US) forces and annexed to Nova Scotia (a predominantly British Colony). During its annexations to Nova Scotia, it was also twice split off as its own colony with a constitution, Lieutenant Governor, Attorney General and legislature (which was never allowed to form), granted to it. The final annexation by Nova Scotia was in 1820 and it was performed under great protest by the executive administration and people of Cape Breton Island. In 1867 Nova Scotia joined Confederation, and the Provinces of Nova Scotia and New Brunswick's provincial constitutions were protected. Whereas Cape Breton Island seeks a return of its constitution and legal system, a question to frame future research that is beyond the scope of this preliminary paper, is what historical, cultural, and legal influences will prospectively influence a society ripe for a potential multi-jural legal system with French and Scottish civil law heritage and a strong traditional Aboriginal presence? The goal of an early review of French civil law in Cape Breton Island and Atlantic Canada, will be to establish a deeper understanding of the regions colonial civil law legacy and to deepen an understanding of the legal history of the region during the period 1608-1763 (intermittent French rule)
\end{abstract}


and 1763-1867 (final British rule).

\section{Keywords}

Colonialism, Jurisdiction, Acadia, France, Quebec, Nova Scotia, Cape Breton, Civil Law, Mi'kmaq, 17th Century, 18th Century, Customary Law, Traditional Law, Complexity and Legal Pluralism

\section{Introduction}

During the later part of the $16^{\text {th }}$ century and first half of $17^{\text {th }}$ century, France began to establish communities and fortifications, initially in Ile Royale (Cape Breton Island) where access and protection of the Gulf of St. Lawrence and cod as a resource were lucrative, then expanded west to the more arable lands of the Bay of Fundy region of what is now Nova Scotia and New Brunswick, and as far west as the New England States, principally within the state of Maine. This region would become known as Acadie (Acadia), and subsequently New France expanded further into the interior of North America. Many of these early fortifications and communities in Ile Royale such as Fort St. Anne (1629-1641) located at what is now known as Englishtown, Victoria County and two other French military forts built adjacent to the fort, were Simon Denys Fort (1650-1659) and Fort Dauphin (1713-1758) (Cape Breton, 2017).

During this early period of French military and colonial administrative entrenchment in New France, the Englishtown area was briefly the capital of Île Royale (Cape Breton Island) from 1713 to 1719. Similarly on the western side of Ile Royale, Fort St. Pierre (1630's-1669), was built at Toulouse (now St. Peter's) as a small, fortified settlement involved in the French fur trade, followed by Fort Toulouse (1715-1745) and nearby the Port Toulouse settlement was established by the French in 1713, located east of Fort St. Pierre (Cape Breton, 2017). And after the Fall of Acadian colonists who had settled west of Cape Breton in the Fort Royal region (Nova Scotia), whom after frequent attacks from New England, the French established a town at Louisburg, 1713, and the Fortress Louisburg (1719-1760), to protect the entrance to the St. Lawrence River and its access to Québec City. This became the capital of Île Royale from 1719 (Cape Breton, 2017).

And so, until the early 1700's the French settlement, administrative centres and colonial power within Acadia were in a state of flux as they dealt with rival British forces and the harsh realities of pioneer life in a new frontier. In addition to the British/French colonial battle for supremacy of the Acadian region and North America during this period and its destabilizing influence on establishing settlement, along with eroded continuity in administration and a regulatory regime, these influences are complexly intermingled with the pre-existing inherent presence of the native Amerindians, primarily the Malecites and Micmawqs (Vanderlinden, 2019: p. 33). The aboriginal people, who deem Acadia as their ancestral lands had their own customary "pre-colonial political order and juris- 
dictional organization without almost any interference of the colonial power, imported normative systems derived from feudalism, the Catholic Church, French colonial order, French provincial customs and family organisation were juxtaposed and interacted, each of them were a well-known part of the Western legal tradition" (Vanderlinden).

\section{Historical Background of New France}

As early as 1504 European fishermen [Bretons and Normans] seem to have been on Canada's north Atlantic coasts, and from which place names such as Cape Breton Island is owed, "which is thought to be the oldest French name in our American geography" (Bourinot, 1892: p. 16). The name Cape Breton has always clung to the island so long frequented by Basque and Breton fishermen of Europe (Bourinot).

"The discoveries of Verrazano in 1521 and of Jacques Cartier in 1585 gave France claim to 'Acadie', Cape Breton and Canada." (Bourinot) England's title came later from the voyages of Jean and Sebastian Cabot, who laid claim for England on Newfoundland (Bourinot), and for whom Cape Breton's world-famous Cabot Trail is named. As early as the late sixteenth century, the region later known as Acadie (Vanderlinden) ${ }^{1}$, and later as Atlantic Canada, attracted France's interest. However, due to limited knowledge of the land, intense fishing competition and the fur trade with the Souriquois (French name for Mi'Kmaq), few colonists are known to have settled there before the 1630s (Caron, 2015: p. 4). "During this period, "particularly after 1640 when Portugal separated from its direct economic and political connection with Spain, Portuguese whaling ships" (St. Clair, 2020: p. 4) along with French and British fishing vessels, would off been found off the Cape Breton Coast (St. Clair).

While Cape Breton Island and other Gulf of St. Lawrence islands including Newfoundland were visited by the Norsemen, the Basques and Bretons, the Cabots and the Portuguese, whose records are uncertain,

"it is sufficient to know that Cape Breton and Acadie or (Bourinot, p. 17)

Cadie, included in the mysterious regions of Norumbega or Norembeque, or Terre des Breton, were visited by Europeans long before the valley of the St. Lawrence was discovered by the Breton Sailor. Indeed, it is contended that the first attempt at European settlement in Canada was on the island of Cape Breton at St. Peters, or Inganiche." (Bourinot)

France's rule during the seventeenth century of Acadie, a largely unpopulated, undeveloped, rugged, wild, and coastal region was problematic. (Caron, p. 5)

"Competition between governors and merchants determined to rule and develop the colony was often violent. Combined with English attacks, these political uncertainties led France to consolidate its North American holdings. King Louis XIV created the Royal Government in New France in 1663,

"'Acadia (in French Acadie) was a colony of New France in north-eastern North America that included parts of eastern Quebec, the present Canadian Maritime provinces, and modern-day United States Maine to the Kennebec River." 
and in Acadia as early as 1670, under the Company of Western Indies' control. Even though Acadia was officially under the Government of Québec's supervisory control, the governors, whose responsibilities were ill-defined, administered the colony with some degree of autonomy vis-a-vis Québec and the motherland. But this very autonomy carried its share of problems for Acadians, given the rapid succession of governors and their frequent transfers of the capital: hence, in the space of a few years, it moved from Port-Royal (NE) to Pentagouët, Jemseg, Nasgouash, and Fort St. John (NB)" (Caron).

There it was, and while Acadie was first administered distinct from New France, in the beginning of the seventeenth century, Sieur de Monts and his French compatriots laid the foundation of the old settlement of Port Royal (Caron) $)^{2}$, (what is now Annapolis, Nova Scotia(Bourinot) ${ }^{3}$ which would serve as the capital of Acadie (Vanderlinden, 1996) ${ }^{4}$ and the beginning of the French regime in the great region of New France. ${ }^{5}$ However, remaining under the watch eye of rivalrous New England and England, "during the seventeenth century it was a question whether Acadie was destined to be an English or a French colony."(Bourinot, p. 14)

"Abundant food supply stimulated strong demographic growth. It is believed that between 1650 and 1755, the growth rate of the population increased annually by 4.5 percent. Birthrates alone explains this growth, the result of a near 100 percent marriage rate and very high fertility rates, as well as low mortality rates due to the quasi absence of epidemic diseases or famine, and easy access to arable land and drinking water. Despite tentative estimates, experts agree that the Acadian population grew from over 400

${ }^{2}$ Ibid, at 5-6. "Acadian families ${ }^{2}$ settled first in the Dauphin River valley, east of Port-Royal. Because the site was unoccupied, they did not have to displace the native population and this allowed them to establish peaceful relations with the Mi'Kmaqs. Indeed, the Acadians set roots in the marshy salines left untouched by the First Nations, in the tidal flood plain which they proceed to dry and put into culture thanks to a complex system of dykes (levées) affixed with drying valves called aboiteaux. This technology was imported from France, probably from the Loudunais region where some early settlers originated. The vast network of dykes the Acadians created inside and beyond the marshlands before 1755, ensured the fertilization of vast meadows for the culture of wheat but also the growth of salt-hay pastures, a particularly attractive source food for cattle. At this time, Acadian agriculture ranked among the most fertile in the world, boasting near constant, abundant crops."

${ }^{3}$ Bourinot, supra note 5, at 14. "Port Royal, known in later times as Annapolis, in honour of a not very brilliant English queen, is therefore the first permanent settlement made by Europeans between Florida and the Arctic regions. Nova Scotia and Cape Breton have the oldest history of any part of the Dominion of Canada."

4"This stretches from 1604, the year of the beginning of the country's first colonization, to 1713, the year of the signing of the Treaty of Utrecht transferring Acadia from France to Great Britain. This treaty left present-day New Brunswick in dispute between the two countries and kept Saint John Island (now Prince Edward Island) and Royal Island, now Cape Breton, in dispute."

5"At the turn of the eighteenth century, New France consisted of four main colonies: at the periphery, Newfoundland, Acadia and Louisiana; in the centre, Canada, firmly entrenched in the St. Lawrence Valley but controlling a network of trading and military posts extending to Hudson Bay, the Great Lakes region and the Mississippi Valley." At

https://www.elections.ca/content.aspx?section=res\&dir=his\&document=chap1\&lang=e 
people in 1671 to more than 1400 in 1730 , for a total of 10,000 to 18,000 people in 1755." (Caron, p. 6)

New England with its proximity by sea and British empire ties, had from its early settlement, watched with adversarial rivalry the growth of the French settlements in Acadie and Canada, and when New England villages were attacked, destroyed and people massacred by raids of Indians and French, they were motivated proactively to make powerful efforts to seize Port Royal, Fortress Louisburg and Quebec (Bourinot, p. 22). Cape Breton during the early 1700s became a strategic geopolitical factor in the affairs of New France. Before the British cession of Nova Scotia and Newfoundland, the French government was advised of the strategic military and economic importance of Cape Breton at the mouth of the Gulf of St. Lawrence and the importance of making one of its harbours (which would become Louisbourg (Bourinot, p. 21) "an 'entrepot' for the trade between Canada, France and the West Indies.” (Bourinot, p. 22)

"Realizing, at last, the serious mistake they had made in neglecting the defences of Acadie, the French government, alter a few mouths of hesitation, quite intelligible in view of the disasters of the great war, set to work to adopt the wise advice of the Randots in 1708 and to make Louisbourg a centre of trade on the Atlantic coast, and a bulwark of their dominion in Canada. Unlike the English colonists, the French on the" St. Lawrence enjoyed no political liberties, but were governed by an aristocratic, illiberal system which crushed out every semblance of self-government and placed them entirely under the rule of the king and his officials in the province (Bourinot) ${ }^{6}$. Their only trade was in furs, and the country gave no evidence of that commercial enterprise that distinguished the English colonies, where ship-building, the fisheries and tobacco cultivation were among the staple industries. In 1714 there were only two towns of any importance in Canada, Quebec and Montreal, and their total population did not nearly equal that of Boston. The whole population of Canada did not exceed twenty-five thousand souls, or about one half that of Massachusetts, of which less than five thousand were capable of bearing arms." (Bourinot, p. 24)

In 1710, the combined forces of British Royal Navy warships and colonial forces from New England captured Acadia's capital, Port Royal for good, and France ceded an ill-defined territory to Britain in the 1713 Treaty of Utrecht (World Heritage Encyclopedia). As well, while France continued to claim those portions of present-day Maine and New Brunswick that constituted part Acadia (along with the Gaspe, Quebec, Ile St. Jean and Ile Royale, it had no formal self-governing colonial structure in this region prior to the British conquest of New France in 1760 (World Heritage Encyclopedia). The first ${ }^{6} \mathrm{Id}$, p. 22 and 33. "I'lie first thing which strikes one on reading the correspondence of the governors and officials at Ile Royale is the neglect invariably manifesto! by France towards the new colony, from its foundation in 1713 down to the fall of Louisbourg in 1758" ("See Brown, Hist, of C. Ll," 222). 
British governor of Nova Scotia at the time was Samuel Vetch, and he took command effective the 1710 capture of Port Royal (World Heritage Encyclopedia). See Exhibit 1.

Exhibit 1. Governors of acadie (New France), 1603-1710

\begin{tabular}{|c|c|c|c|}
\hline Governor & Term & $\begin{array}{l}\text { Granting } \\
\text { authority }\end{array}$ & Notes \\
\hline $\begin{array}{l}\text { Pierre Dugua, Sieur de } \\
\text { Monts }\end{array}$ & $1603-1608$ & $\begin{array}{l}\text { French } \\
\text { crown }\end{array}$ & $\begin{array}{l}\text { Dugua and Samuel de Champlain established the first settlement in Acadia on } \\
\text { St. Croix Island in 1603. After a harsh winter, they moved across the Bay of } \\
\text { Fundy to establish Port Royal. }\end{array}$ \\
\hline $\begin{array}{l}\text { Jean de Biencourt de } \\
\text { Poutrincourt et de } \\
\text { Saint-Just }\end{array}$ & $1606-1615$ & $\begin{array}{l}\text { French } \\
\text { crown }\end{array}$ & $\begin{array}{l}\text { Poutrincourt's first charter was revoked in } 1607 \text {; he received a new grant from } \\
\text { King Henry in 1608, and resettle Port Royal in } 1610 \text {. He only effectively } \\
\text { governed until 1613, when Samuel Argall destroyed Port Royal in a raid. Only } \\
\text { a few colonists remained, under Biencourt, who was Poutrincourt's son. }\end{array}$ \\
\hline $\begin{array}{l}\text { D Charles de Biencourt } \\
\text { de Saint-Just }\end{array}$ & $1615-1623$ & $\begin{array}{l}\text { French } \\
\text { crown }\end{array}$ & $\begin{array}{l}\text { Biencourt inherited the commission upon his father's death. The colony } \\
\text { remained small, subsisting on fishing and the fur trade. }\end{array}$ \\
\hline William Alexander & $1621-1629$ & $\begin{array}{l}\text { Scottish } \\
\text { crown }\end{array}$ & $\begin{array}{l}\text { Alexander was granted a proprietorship to establish New Scotland. Despite a } \\
\text { lack of settlement, his grant was renewed in } 1625 \text {. Alexander and his son } \\
\text { attempted to interest Claude de Saint-Étienne de la Tour, who had come to } \\
\text { Acadia with his son Charles on Poutrincourt's expedition. }\end{array}$ \\
\hline $\begin{array}{l}\text { William Alexander the } \\
\text { younger }\end{array}$ & $1629-1632$ & $\begin{array}{l}\text { Scottish } \\
\text { crown }\end{array}$ & $\begin{array}{l}\text { Alexander inherited his father's claim. He settled Port Royal and an outpost } \\
\text { on Cape Breton Island with Scottish colonists in 1629. The Alexander's claim } \\
\text { was extinguished in the } 1632 \text { Treaty of Saint-Germain-en-Laye, and the Scots } \\
\text { abandoned the colony. }\end{array}$ \\
\hline $\begin{array}{l}\text { Charles de Saint-Étienne } \\
\text { de la Tour }\end{array}$ & $1631-1644$ & $\begin{array}{l}\text { French } \\
\text { crown }\end{array}$ & $\begin{array}{l}\text { La Tour inherited Biencourt's commission, but this was not recognized by the } \\
\text { crown. He built up a strong presence at Cape Sable, and was issued a charter } \\
\text { in his own right in } 1631 \text {. }\end{array}$ \\
\hline Isaac de Razilly & $1632-1635$ & $\begin{array}{l}\text { French } \\
\text { crown }\end{array}$ & $\begin{array}{l}\text { Razilly's charter conflicted with La Tour's, and King Louis XIII's division of } \\
\text { their authorities was geographically uninformed. Although Razilly and La } \\
\text { Tour had an amicable relationship, their successors battled each other for } \\
\text { control of various parts of Acadia. Razilly established his base at La Héve on } \\
\text { the Atlantic coast. }\end{array}$ \\
\hline $\begin{array}{l}\text { Charles de Menou } \\
\text { d'Aulnay }\end{array}$ & $1635-1650$ & $\begin{array}{l}\text { French } \\
\text { crown }\end{array}$ & $\begin{array}{l}\text { D'Aulnay governed on behalf of Claude de Razilly, who inherited his brother's } \\
\text { charter but was unable to come to Acadia. Disagreements between La Tour } \\
\text { and d'Aulnay broke out into open violence in the late 1630s. Both appealed to } \\
\text { New England colonists at one time or another for assistance. He succeeded in } \\
\text { having La Tour "discredited" in 1644, and used military force in an attempt to } \\
\text { drive La Tour from his holdings. }\end{array}$ \\
\hline $\begin{array}{l}\text { Charles de Saint-Étienne } \\
\text { de la Tour }\end{array}$ & $1653-1654$ & $\begin{array}{l}\text { French } \\
\text { crown }\end{array}$ & $\begin{array}{l}\text { La Tour refused to surrender territories he was holding when driven from } \\
\text { office in 1644, and appealed to New England colonists, with whom Acadians } \\
\text { had been trading, for aid. When d'Aulnay died in 1650, La Tour went to } \\
\text { France, was vindicated in inquiries, and returned to Acadia in } 1653 \text { with a new } \\
\text { commission. He cemented his interests in Acadia by marrying d'Aulnay's } \\
\text { widow. Following the capture of Port Royal by an English expedition led by } \\
\text { Robert Sedgwick, La Tour was captured and sent to England. In } 1657 \text { La Tour } \\
\text { sold his claim to Thomas Temple and William Crowne, which included } \\
\text { recognition by Oliver Cromwell as baronet of Nova Scotia, a title La Tour's } \\
\text { father had been granted by the Alexanders. }\end{array}$ \\
\hline
\end{tabular}


Continued

\begin{tabular}{|c|c|c|c|}
\hline John Leverett & $1654-1657$ & $\begin{array}{l}\text { English } \\
\text { military } \\
\text { command }\end{array}$ & $\begin{array}{l}\text { Leverett was placed in command of the sites captured by Sedgwick in his } 1654 \\
\text { expedition. His command ended with the arrival of Thomas Temple. }\end{array}$ \\
\hline Nicolas Denys & $1654-1688$ & $\begin{array}{l}\text { French } \\
\text { crown }\end{array}$ & $\begin{array}{l}\text { Denys had arrived in Acadia as one of Isaac Razilly's lieutenants. He was } \\
\text { granted a charter for coastal areas from Canso north along the coast of the } \\
\text { Gulf of Saint Lawrence, including present-day Prince Edward Island and Cape } \\
\text { Breton Island, and a monopoly on fishing rights as far south as Virginia. He } \\
\text { established several communities on the territory, but none grew to any } \\
\text { significant size, and his charter seems to have been extinguished with his } \\
\text { death. He spent much effort attempting to enforce his monopoly on fishing } \\
\text { rights. }\end{array}$ \\
\hline $\begin{array}{l}\text { William Crowne and } \\
\text { Thomas Temple }\end{array}$ & $1657-1670$ & $\begin{array}{l}\text { The } \\
\text { Protectorate }\end{array}$ & $\begin{array}{l}\text { Crowne and Temple claimed Nova Scotia as a proprietorship authorized by } \\
\text { Treaty of Breda, which ended the Second Anglo-Dutch War, called for the } \\
\text { return of Acadia to France. Crowne and Temple consequently abandoned } \\
\text { their claim in } 1670 \text {. }\end{array}$ \\
\hline Emmanuel Le Borgne & $1657-1667$ & $\begin{array}{l}\text { French } \\
\text { crown }\end{array}$ & $\begin{array}{l}\text { Le Borgne was a creditor of d'Aulnay's. Shortly after La Tour's return to } \\
\text { Acadia in 1653, Le Borgne arrived to negotiate for payment of the debts owed } \\
\text { him. His efforts to collect disturbed by the English intervention in 1654, he } \\
\text { acquired a charter from King Louis XIV. Unable to collect because of Crowne } \\
\text { and Temple's occupation of La Tour's holdings, his land grants were renewed } \\
\text { in 1667, but his governorship went to his son. }\end{array}$ \\
\hline
\end{tabular}

Alexandre Le Borgne de Belle-Isle

$1667-1670$

French crown

Hector d'Andigné de Grandfontaine

1670-1673

French crown

Belle-Isle, despite the Treaty of Breda's terms, was unable to take control of Acadia from Crowne and Temple because France could not guarantee preconditions to handover. He consequently never actually governed, and the Englishmen turned Acadia over to his successor, Hector d'Andigné de Grandfontaine.

Grandfontaine, a military officer, spent most of his term in office restoring order after the preceding years of chaos. He established his headquarters at Fort Pentagouet, partly as a deterrent against the English, who also claimed the area.

Most of Chambly's term in office was disrupted by the attack of the Dutchman

Jacques de Chambly 1673-1677

French crown Jurriaen Aernoutsz, who seized a number of the key communities and claimed Acadia as New Holland. Aernoutsz left John Rhoades in command.

Dutch Rhoades, an Englishman from Massachusetts, was captured and taken to

John Rhoades

1674-1675 military command

Boston after men under his command captured New England trading ships in Acadian waters. France was consequently able to recover the territory without resistance.

Dutch West Van Steenwyk was a Dutch merchant from New York. The Dutch West India

Cornelius Van

Steenwyk

India

Company

Pierre de Joybert de Soulanges et de Marson 1677-1678 (commandant)

Michel Leneuf de la Vallière de Beaubassin
$1678-1684$
French crown

French crown
Company, seeking to capitalize on Aernoutsz's actions, granted him a commission as Governor of New Holland. Because of Rhoades' capture by the English, this claim existed only on paper.

In Joybert's brief term in office he moved the capital to Jemseg, where he had been granted land for his military service. He died in 1678 .

Beaubassin replaced Joybert as commandant, and based himself primarily at Beaubassin on the Isthmus of Chignecto. Commissioned as governor in 1683, he was criticized for allowing New Englanders to fish in Acadian waters (against orders from the king forbidding such activity). 


\section{Continued}

François-Marie Perrot 1684-1687

Louis-Alexandre des

Friches de Meneval

$1687-1690$

French

crown

English

Charles La Tourasse

1690-1691

military

Comman

Joseph Robineau de Villebon (commandant)

French crown

Claude-Sébastien de

Villieu (acting

commandant)

$1700-1701$

French

crown

Jacques-François de Monbeton de Brouillan

$1701-1705$

French crown

Simon-Pierre Denys de Bonaventure (acting)

French crown

Daniel d'Auger, sieur de Subercase

1706-1710

French crown
Little is known of Perrot's time as governor of Acadia. He apparently did not actually arrive at Port Royal until 1685, and sought to monopolize trade for his own benefit. He also permitted New Englanders to fish in Acadian waters in exchange for a small fee.

Meneval, a lieutenant in the troupes de la marine, worked to improve Acadia's defenses against English attacks. In 1690, after the Nine Years' War broke out, he surrendered Port Royal, whose fort was only half-finished, to an expedition led by William Phips.

La Tourasse was a sergeant in the French garrison at the time of Phips' expedition. Phips placed him at the head of a council of locals (that notably included Edward Tyng)

Robineau arrived at Port Royal not long after Phips departed. As de facto French commander, he immediately relocated the seat of government to Jemseg, and was eventually given a commission as commandant of Acadia in 1691. He directed French military efforts against New England until the end of the Nine Years' War in 1697. Villebon's treatment of the inhabitants was at times controversial.

Villieu governed after Villebon's death until his successor de Brouillan arrived. He also acted as acting commander during some of de Brouillan's absences from the colony.

De Brouillan's first commission was as commandant; he was elevated to governor in 1702 . He was a corrupt and sometimes cruel administrator, who thought poorly of the inhabitants. He did restart construction of fortifications at Port Royal and organized the defenses there against an anticipated attack in 1704 by Benjamin Church. He left for France shortly after to defend himself against many charges, and died at Chedabouctou on his way back in 1705.

Bonaventure petitioned to formally replace de Brouillan after the latter's death, but the position went instead to the governor of Plaisance, Daniel d'Auger de Subercase. Bonaventure governed until Subercase's arrival in 1706.

Subercase successfully repulsed two attempts by English colonists to take Port Royal in 1707 . He orchestrated highly successful privateering operations against the New Englanders, but was unable to prevent the capture of Port Royal in 1710 when the British provided the New Englanders with significant naval resources and regular troops to take the Acadian capital for the last time. After his surrender, the British renamed the town Annapolis Royal and installed Samuel Vetch as the new Governor of Nova Scotia, 1710-1713.

The British conquest of Port Royal (Acadie's capital ${ }^{7}$ ) in 1710 also helped drive a wedge between Acadians and Mi'kmaq in western Acadia, which after

7"While Port Royal had been the seat of Acadian government pretty much from the beginning, its importance slipped from 1670 with the seat of government being at either Pentagoet (Castine, State of Maine) or from one of the forts on the St John It was determined by the French authorities, at some point after its official handback, by the Treaty of Ryswick (1697), that Port Royal should once again be the capital of Acadia." http://www.blupete.com/Hist/NovaScotiaBk1/Part2/Ch07.htm

${ }^{8}$ World Heritage Encyclopedia, "Most of Acadia's French governors operated under commissions given by the French crown ... Some of the later appointments were not as governors; these were military men who were commissioned as commandant of Acadia, and acted under the direction of the Governor General of New France." 
the fall of Port Royal became known as western Nova Scotia and part of the British ruled colony of Nova Scotia (The University of Maine). The Mi'kmaq whom were loyal to the French, and the Acadians, took different approaches to their relations with the British whom took over control of Nova Scotia upon its partition from the rest of Acadie. The Mi'kmaq whom focussed on preventing settler encroachments onto their lands, were opposed to any cooperation with Britain, whereas the Acadians of Western Nova Scotia because of their agricultural industry sought trade where they could find it (Morris, 2012, pp. 29-30). In eastern Nova Scotia and Île Royale (Cape Breton), where a French imperial presence was retained, and where agriculture had not been developed there was little incentive for northeastern Acadians to work with the British. (Morris, p. 30)

The French Governor Subercase, who in 1710 surrendered Port Royal to General Nicholson, had a commission from the French king as "Governor of Acadie, Cape Breton and the adjacent islands and countries. By his surrender then Cape Breton came also into the possession of England until 1713, when France awoke to its importance." (Bourinot, p. 23)

The Treaty of Utrecht was the first checkpoint given to France colonial designs in America. (Bourinot, p. 20) Under Utrecht whilst France lost title to Nova Scotia (a portion of Acadie) it retained rule of the remining portion of Acadie and provided that this island (Ile Royale), "as also all others both in the mouth of the River St. Lawrence and in the gulf of the same name, shall hereafter belong of right to the king of France, who shall have liberty to fortify any place or places there." (Bourinot, p. 22) After the conquest and Treaty of Utrecht, western Nova Scotian Acadians hyperbolize that Acadia disappeared as a polity. (Caron, p. 7) However, France kept a large portion of remaining New France and the St Lawrence Gulf's Islands, which collectively are referred to as Acadia, or part of the former Acadie, and more popularly known today, less the State of Maine, as the Maritime Provinces and with Newfoundland, as Atlantic Canada. The new colonial British authorities acquired Acadia they believed, which they renamed Nova Scotia, while the French troops retreated to present-day New Brunswick. However, while per the terms of the Treaty, France was to surrender Acadia to Great Britain, "in its totality within its former borders," the Treaty did not however specify what these former borders were. "For France, they were limited to the Nova Scotian peninsula. For Great Britain, Acadia extended to New Brunswick as well. This difference in opinion, among other factors, led to the Seven Years' War forty years later" (Caron, p. 7). After 1713, many western Nova Scotia Acadians from the Port Royal region settled in large number on Île-Saint-Jean (PEI), where they initiated a market gardening production to supply the Fortress of Louisburg built on Île Royale (Cape Breton Island). (Caron, p. 8) For those Acadians who remained in the Port Royal region the colonial transfer hardly changed anything for them on a daily basis. (Caron, p. 8)

"Used to an ineffective administration caused by a high rate of turnover, or absent, governors, they continued to lead quiet and largely autonomous 
lives on their land. Nevertheless, in the 1710s and 1720s, and again the 1740s, some of them participated in joined resistance against British troops. These incidents were often at the hands of young men who took part in the numerous and well organised Aboriginal ambushes or raids. On other occasions, Acadians (coming from what would later be New Brunswick) participated, willingly or forcibly, in French attacks. However, at all times, even during the Deportation, these were isolated skirmishes, although they caused the colonial authorities to fear their subjects, and most of all a handful of priests crisscrossing the territory. Few priests lived in French Acadia, particularly after 1713." (Caron, p. 9)

After 1713, Acadian relations with the British colonial authorities (as well as French and British relations) began to deteriorate and worsen in the 1740s. (Caron $)^{9}$ The British governing class of the territory were greatly distrustful of their newly conquered French-speaking and Catholic subjects. (Caron) The Acadians refusal to swear an oath of allegiance and consent only to a conditional oath only was scorned by the English colonial authorities and opposed by the British Colonial Office. (Caron)

"Hence, by virtue of the British law, they were in effect unlawful. If their stated neutrality in the conflicts between great European powers earned them the nickname 'Neutrals' by the governors of Nova Scotia, it did not earn them the latter's trust either quite the opposite. Between 1740 and 1754, as threats of war between France and the United Kingdom became increasingly palpable, mounting tension ensued in Nova Scotia." (Caron) See Exhibits 2 and 3:

\section{EXHIBIT 2}

French Governors of Ile Royale (a.k.a. Cape Breton Island, from 1713-1759

(Bourinot, p. 21)

M. de Costabelle, 1712-1717;

M. de St Ovide, 1718-1735;

M. de Brouiuan, 1736-1738;

M. de Forant, 1739-1740;

M. Puquesnel, 1741-1744;

Major Dachambon, 1745;

[the English governors from 1745 to 1749 were Warren and Pepperrell (joint), Commodore Knowles and Colonel Hopson;]

M. des Herbieres, 1749-1751;

M. le Comte de Raymond, 1751-1754;

M. d'Aillebout, 1754;

M. de Drucour, 1754-1759.

${ }^{9}$ Id. "For the local authorities, all Acadians were traitors and potential rebels. During the first years of the new regime, they failed to convince them to pay allegiance to the British Crown. Most Acadians refused to take up arms against the French or the Aboriginals which an unconditional oath would have obliged them to." 
Note: This French Governors of Ile Royale list above is made up from M. Marinette's summary of papers in the French archives relating to Ile Royale. (“Canadian Archives," 1SS7.) M. de St. Ovide was also known as M.de E Ovide de Brouillan, and it is a question whether the same person was not governor from 1736 to 1738 , but I have not been able to clear up this doubt.

\section{EXHIBIT 3}

British Governors of the Colony of Cape Breton, 1784-1820 (Krause)

Under British rule, when Cape Breton was twice partitioned by royal charter from Nova Scotia, and created its own Colony, until its re-annexation in 1820:

Major Frederick Wallet DesBarres, 1784-1787;

Lt.-Colonel Macarmick, 17S7-1795;

Attorney-General D. Mathews, president of council, administrator, May 27, 1795-June 29/98;

Brigadier-General Ogilvie, president of council, administrator, June 29, 1798-June 21, 1799;

Brigadier-General Murray, June 21, 1799-Sept. 16, 1800;

Major General Despard, Sept. 16, 1800-July 6, 1807;

Brigadier-General Nepean, July 6, 1807-June 1, 1813;

Brigadier-General Swayne, Jan. 1, 1813-Feb. 6, 1816;

Lt.-Colonel Fitzherbert, February 5. 1816-Nov. 4, 1816;

Major-General Ainslie, November 4, 1816-June 22, 1820;

Captain David Stewart, administrator, until 9th October, 1820, when NS re-annexed Cape Breton.

The treaty of Aix-la-Chapelle 1748, which concluded the European War of the Austrian Succession also represented "a temporary truce in the Anglo-French conflict in India and North America. In North America colonists unwillingly ceded the French fortress of Louisburg, in order to secure the return of Madras to Britain." (Oxford) The treaty also left many issues of conflict unresolved and war (the Seven Years War, 1756-1763) broke out again eight years later.

"it was the persistency of the French to regain possession of so valuable a bulwark to their great dominion in Canada that forced the English ministry to restore it at a time when the nation was disheartened at the results of the war on the continent and inclined to call a truce. It was only a truce in Europe, [a mere pause in the struggle, during which both parties hoped to gain strength for a mightier conflict which they saw impending]. In America it was not even a cessation of hostilities until the war was again formally proclaimed between France and England in 1756." (Bourinot, p. 58)

The 1750s and 1760s was a period of great geopolitical upheaval in Northeastern North America. (Morris, p.V, FN 1) The Seven Years' War (1754-1763) saw Britain and France clash for control of the North American continent to expand their empires. (Morris, p., at V) Ultimately, the war brought about dramatic changes in the Northeast. After capturing Fort 
Beauséjour (MyNewBrunswick) in 1755,

"Britain rounded up and deported the Acadians of Nova Scotia to France and the Thirteen Colonies because they refused to swear an unconditional oath of allegiance to the British Crown. The Acadians were willing to swear a conditional oath to Britain that would grant them freedom to practise Catholicism, but not commit them to take up arms in imperial conflicts. Acadians in the French colonies of Île Royale (present-day Cape Breton) and Île Saint-Jean (present-day Prince Edward Island) were also deported following the British siege of the French fortress of Louisbourg in 1758." (Morris, at FN3)

As the British/French clash for control of America continued amid the seven years war, by the end of 1760 Québec and Montréal also fell under siege and into British hands, which spelled the end of the French Colonial Empire in North America. (Morris, p.V) The Treaty of Paris ended the Seven Years' War in 1763, and resulted in France ceding the vast majority of its North American empire to Britain, with the exception of retaining the islands of Saint-Pierre and Miquelon, located twenty-five kilometres from the south coast of Newfoundland, which ensured that "France retained its exclusive fishing rights on Newfoundland's French Shore, which had been established in 1713. At the end of 1763, France's official colonial possessions in North America amounted to two tiny islands in the North Atlantic and exclusive fishing rights in northern Newfoundland." (Morris, p. 2)

The Seven Years' War represented "a fundamental historical fissure," (Morris) which in many ways in lieu of the British Conquest of French North America marked a breaking point in Canadian/American history, and deepened a cultural divide between English and French Canadians. (Morris, p. 4) In 1763 the treaty of Paris was signed and France ceded to England:

"Canada with all its dependencies as well as the island of Cape Breton and all other islands and coasts in the Gulf and River Saint Lawrence and in general everything that depends on the said countries, islands and coasts with the sovereignty, property and possession, and all rights." (Bourinot, pp. 78-79)

While the proclamation dated the 7th of October, 1763, King George the Third annexed Ile Royale (renamed Cape Breton Island ${ }^{10}$ ) and St. John's (renamed Prince Edward Island) "with the lesser islands adjacent thereto to our government of Nova Scotia" (Bourinot, pp. 79-80), the return of Saint-Pierre and Miquelon to France allowed Mi'kmaq, French, and Acadian communities to remain connected through kinship, religion, and commerce, despite the fact that Britain was the dominant imperial power in the region. And, subsequently

${ }^{10}$ For the sake of historical accuracy the term île Royale will be used when referring to the territory before 1763, and Cape Breton or Cape Breton Island will be used for any discussions after 1763 until annexation by Nova Scotia in 1820. Similarly, Acadia will be used for dates before 1713, and Nova Scotia will be used for any references to that portion of Acadia after 1713. 
French, Acadian, Mi'kmaq and later Scottish (traditional allies of the French) settlers influence persisted in the post-Conquest period, allowing French cultural and economic structures in North America to persist after the fall of New France. (Morris, p. 5) 11

In the English language dominated continent which prevailed after 1763, there is a societal tendency to downplay the role of the French and Acadians in North America and particularly the Northeast, the former New France colony known as Acadie, partly due to the region after the expulsion of the Acadians becoming largely an English Speaking region. "Focusing on the rapid Anglicization of Acadie and the Northeast presupposes that the French and Acadians had little presence or influence in the region following the deportation of the Acadians in 1755, and the conquest of New France in 1760." (Morris, p. 9)

French Acadian continuity in the post- 1763 Northeast lay hidden beneath a mask of widespread geopolitical change. (Morris) While the Treaty of Paris shifted imperial boundaries, it didn't greatly affect the existing social and cultural realities for the peoples of the Northeast. (Morris) Remarkably, following the Seven Years' War, those two small islands Saint-Pierre and Miquelon (retained by France) (Morris) ${ }^{12}$ "played a crucial role in maintaining continuity in the commercial, cultural, and kinship relations between Mi'kmaq, French, and Acadian populations of the region." (Morris, pp. 30-31)

Saint-Pierre provided a maritime "environment that was conducive to the ${ }^{11}$ Colin Calloway noted that 1763 "initiated a world of upheaval that remade America" and "ensured that America would be English speaking, not French speaking..." However, geopolitical changes did not immediately alter the social and cultural realities in France's former colonies. Furthermore, the fact that France ceded its colonies to Britain in 1763 did not mean that the triumph of English society in North America was inevitable. As Phillip Buckner and John Reid have argued, "Even after the Treaty of Paris of 1763 secured for the British what they had won on the battlefield, it was not inconceivable that France might have returned or assisted the thirteen colonies during the American Revolutionary War in taking from Britain what Britain had taken from France.” The fact that France never recaptured its colonies does not mean that it was an insignificant actor after 1763. Despite its military defeat in the Seven Years' War, France retained social and cultural influence in North America.

${ }^{12} \mathrm{Id}$, at II. See also 30-31. "The majority of those who settled in Saint-Pierre were former fishermen and traders from Île Royale. As Michel Poirier noted, Île Royale became 'la principale source de peuplement pour cet archipel [Saint-Pierre] destiné à reprendre la succession de l'établissement de l'île Royale.' In April 1763, 300 traders and fishermen who had found sanctuary in La Rochelle and St. Malo after the Acadian deportations were sent to Saint-Pierre, along with fifty French administrators. Later that year another 100 former inhabitants of Île Royale settled in Saint-Pierre.72 However, Saint-Pierre was not strictly an Acadian settlement; it was also home to French administrators, traders, ship captains, soldiers, and fishermen. Many of these fishermen and traders were former French inhabitants of Plaisance who migrated to Île Royale after 1713. In contrast to Saint-Pierre, Acadians from Île Saint-Jean, which was known as St. John's Island from 1763 to 1799, and Nova Scotia constituted the main body of inhabitants who settled at Miquelon. In 1763, the French Crown determined that besides military personnel and administrators, only fishermen and their families should be allowed to settle at Saint-Pierre and Miquelon. Governor D'Angeac was ordered to restrict the number of Acadian farmers on the islands. However, over 250 Acadians arrived in Miquelon from Boston and Halifax without permission during 1763 and 1764. Two separate groups arrived in Miquelon in October 1765, one made up of seventy-two individuals from Beauséjour, and a second containing 115 individuals from St. John's Island, Halifax, Beauséjour, Beaubassin, and a small contingent from Cape Breton." 
transplanting of Île Royale society" (Morris, p. 32), particularly French colonists from the conquered Fortress Louisburg. Saint-Pierre rapidly became populated largely by French and Acadians from Île Royale. (Morris, pp. 30-31) A diminutive island in terrain, Saint-Pierre developed into a fishing and trading outpost in lieu of its location in the North Atlantic, and its sheltered harbour. (Morris, pp. 32-33) These former Île Royale inhabitants were accustomed to a fishing and trading lifestyle and readily continued their commercial lifestyle in Saint-Pierre. (Morris) The close ties between Acadians, French, and Mi'kmaq of Île Royale (Morris) were also transported to Saint-Pierre. Saint-Pierre was home to a mixed French-Acadian population that had shared religion, kinship and regular contact with Mi'kmaq of southern Newfoundland. (Morris, p. 33) "This contact allowed Mi'kmaq, Acadians, and French to maintain and expand the relationships they had formed on Île Royale before the Conquest." (Morris)

Whereas Acadia, or the old colony of Nova Scotia, was ceded to the British by French in 1713 by way of the Treaty of Utrecht, New Brunswick, Ile Saint Jean and Ile Royale were retained by France, briefly until British gained sovereignty of New Brunswick in 1759, remained part of the colony of Nova Scotia until given independent colonial status in 1784. Prince Edward Island (PEI) (Caron, p. 13) ${ }^{13}$ and Cape Breton similarly remained under French sovereignty, until 1763, when they were ceded to Britain at the Treaty of Paris and annexed to Nova Scotia in the Royal Proclamation. Along with New Brunswick, Cape Breton became an independent colony in 1784, and Cape Breton remained so until 1820, at which point it was re-annexed to Nova Scotia.

\section{The Civil Law in New France}

In this paper I am not dealing with jurisdictional diversity during the various periods of Acadian legal history, which are difficult to study due to the lack of sources, and in my view feature diversity and New France's (including Acadie) "quasi-total lack of hierarchy as the main characteristics" (Vanderlinden, 2019: p. 35). But what is New France and where is Acadia (Acadie)? In a Canadian context, New France or northern France, as it is called in some documents, is the whole of French interests formed within Canada by France in the seventeenth and eighteenth centuries. New France is known roughly as, the southern part of the present province of Quebec, Acadia (Vanderlinden, 1996) ${ }^{14}$ and Newfoundland. Jacques (Vanderlinden, 1996) ${ }^{15}$ But, where is Acadia? (Vanderlinden, 1996) Acadia was the name the French gave for the region of French settlers we know

13“The old Île-Saint-Jean also became a separate colony as early as 1764 and took the name of Prince Edward Island in 1799”, and a colonial government was established on Prince Edward Island in 1769 which marked the Province's debut as an independent colony, and an elected assembly first met in the colony in 1773. See

https://www.thefreelibrary.com/The+Prince+Edward+Island+Legislative+Assembly.-a0261632026

14"Acadia was an important geographic position. Its territory controlled the Gulf of St. Lawrence, and was close to valuable fishing grounds, shipping routes and the British colonies along the Atlantic seaboard. This was not very surprising that the French and British were constantly battling for control of all of it." 
today as Nova Scotia (including Cape Breton Island), Prince Edward Island, New Brunswick, the Gaspé Penisula (Quebec) and Maine, USA (The Fall of New France). It is also worth noting that "because Acadians lived for a long time in isolated communities they didn't have a lot of contact with other French-speaking people. This means that Acadian French sounds a lot different than French spoken in Quebec or France today" (The Fall of New France).

1604 the first Acadian settlement, was established by Samuel de Champlain and Pierre Du Gua, Sieur de Monts, who was appointed lieutenant-general for New France, 1603, (OHT) at St. Croix Island, ME (near the present day Maine/New Brunswick international border) and it represented France's first colonization in North America, (OHT) followed by the establishment a trading post at Québec in $1608 .{ }^{16}$ And so, it can be said that at this point with French settlement in process and a colonial lieutenant-general to administer the French empires interests,

"French law was received in the Canadian colony. Despite claims of the Sovereign Council that it had to register French laws for them to be in effect in the colony, its leading legal officials, the intendant and the attorney general, were metropolitans and servants of empire who enforced all French legislation. Although the situation was different in continental Acadia and the fur trading territories in the west, ${ }^{1}$ and which had few formal administrative structures, the superior councils of Louisbourg and New Orleans applied the same law in Cape Breton and Louisiana." (Dickinson, 1996: p.32)

According to French royal theory, justice was free to all subjects. "With its Civil Law codified in the form of the Coutume (Dickinson) de Paris, and an inquisitorial criminal procedure, the legal culture of New France differed dramatically from the English common law being simultaneously transplanted to New England." (Dickinson) However, venality circumvented the application of the royal theory of "justice free to all subjects",

"since officials expected a decent return on their investment and the royal treasury never had the means to pay proper salaries or to buy back the of-

${ }^{15}$ Id. "However, very quickly, the terminology of the legislative acts of the time seems to be considered equivalent to New France and Canada; thus there is a first shift in assimilation of the main part (Canada where the capital of the colony is located, Quebec) with the whole (New France). As, in addition, the main movement of research and publications relating to the history of the law of this part of Canada today is manifested in Quebec, the confusion between New France, Canada (in the sense of the time) and the present province of Quebec tends to strengthen. Reading some books or studies of the history of law devoted to New France in which there is no mention of Acadia only reinforces this first impression."

16“July 1608: Samuel de Champlain founds Quebec. September 1759: Quebec surrenders to the English. In the intervening 150 years, a colony of French-speaking Catholics had put down roots in the St. Lawrence Valley and spread west and south into the land of the Illinois and to Louisiana. This was New France. Compared to its neighbour, New England, New France grew geographically by leaps and bounds; demographically, however, it moved at a snail's pace. Under the Treaty of Utrecht, France ceded present-day Nova Scotia, as well as Hudson Bay and Newfoundland, to England in 1713. Fifty years later, under the Treaty of Paris, France ceded the rest of New France." https://www.elections.ca/content.aspx?section=res\&dir=his\&document=chap1\&lang=e 
fices. Summary jurisdiction did take some of the sting out of court costs in a wide-ranging set of cases, but costs remained an important factor limiting access to judicial institutions." (Dickinson, p. 33) ${ }^{17}$

The Civil law of France which would be carried with its settlers to New France (Including Acadie) "depended on a confusing mixture of customs in the north and Roman law in the south." (Dickinson) To standardize its civil law, the French crown ordered codification of its customary law in the fifteenth century, which dragged on through the following century. (Dickinson, p. 6) The publication of codified French customary law (e.g., the Coutume de Paris in 1580), helped to ensure a more uniform law, albeit "one that was subject to interpretation and modification through decisions establishing new precedents." (Dickinson) "Although it was hoped that the Coutume de Paris would become the model for all of northern France, provincial parlements (law courts)," (Dickinson) in France, resisted the encroachment of a central body of law. (Dickinson) Nevertheless, the Coutume de Paris represented newly codified law which did not necessarily gain ready acceptance (Dickinson, p. 7) ${ }^{18}$ in the new world (New France), although it presumably served as a reference for the executive administrators of New France. (Dickinson, p. 6) During the same period, France consolidated criminal law by enacting the Criminal Ordinance of 1670. (Dickinson, p. 8)

"In the inquisitorial system, sharply influenced by Roman law, crucial stages of the trial were conducted in camera so that witnesses could testify without fear of retaliation. Since personal honour was highly prized, secrecy could protect innocent people from malicious prosecution. Even the attorney-general, who acted as prosecutor, was absent from the courtroom during testimony, lest he influence the witnesses. Since in theory the accused did not know the exact nature of the charges or the elements of evidence against him or her, a convincing alibi was more difficult to fabricate. Because of distrust of glib lawyers, this system prohibited legal counsel for the accused, as did the English common law formally until 1836. Since discovery of all pertinent facts was essential, the judge was not limited to the evidence provided by the accusation but had to validate all the facts by con-

\footnotetext{
${ }^{17} \mathrm{P}$. . "Since justice was considered a foremost responsibility of kingship, the crown consistently tried to speed up the judicial resolution of private conflicts, principally by enlarging its summary jurisdiction. The 1579 Ordinance of Blois defined summary jurisdiction as covering all personal cases involving less than 10 livres, to be judged in court without recourse to procureurs (attorneys who represented parties in court) or avocats (barristers) and without court fees. The 1629 Code Michau further enlarged this definition raising the amount to 20 livres and stipulating that judgments were without appeal. The final modification, incorporated in the Civil Ordinance of 1667, raised the monetary limit to 200 livres for personal cases and to 1000 livres for almost all cases involving commercial transactions, wages, and leases. Judges were ordered to render a decision immediately without fees."

${ }^{18}$ Ibid. "Unable to override local customs, the crown did succeed in imposing uniform procedure through its Civil Ordinance of 1667. It also enacted new legislation to regulate matters outside the old law such as the slave trade (Code Noir, 1673) or inadequately covered in customary law such as trade (Code Marchand, 1673) and maritime affairs (Ordonnance de la Marine, 1681).” Id, at 7.
} 
ducting an independent investigation. The effectiveness and fairness of this system depended on the conscientiousness and impartiality of the judges.

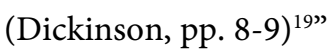

In 1663 the era of private monopolies in the colonies came to an end and New France became a royal colony ${ }^{20}$ and when the crown took over New France, "judicial reform was high on the monarchy's agenda and the colony was a virtual tabula rasa on which to impose a new order." (Dickinson, pp. 35-36) Furthermore New France and Acadie represented a fertile legal laboratory for the introduction of new French civil law measures as there were no long established local customs and no powerful interest groups long enough societally rooted to resist change. (Dickinson)

France took important steps to ensure the uniformity of the implementation of its laws and to lessen administrative costs. (Dickinson)

"The colony did benefit from imposition of the Coutume de Paris and of a coherent system of weights and measures. Venality was not introduced and salaries were higher than those common in France, despite the persistent belief in court circles that New France was a drain on the royal treasury. Since the crown considered avocats the main villains in prolonging trials by playing on procedure, they were not allowed to practise in the colony before the Conquest. As a result, cases were slightly less expensive and resolved more quickly. ${ }^{18}$ But the basic administrative structures of $\underline{\text { France }}$ were repeated for New France. There was no attempt to abolish existing seigneurial courts or to impede creation of new jurisdictions." (Dickinson) $)^{21}$

The 1664 edict establishing the Compagnie des Indes occidentales, made the

${ }^{19}$ Id, at 8-9. "In seventeenth century French law, individuals could sue for civil damages but only the king's attorney could initiate criminal proceedings. The judge had to determine the nature of alleged crimes and the identity of the guilty party. Although judges had great latitude in gathering evidence, they had to follow strict guidelines in its evaluation. Evidence was weighed and divided into three different categories: 'complete proofs,' 'proximate indications,' and 'remote indications.' Eyewitness testimony was considered best evidence, but it had to meet certain criteria. Two eyewitnesses who agreed on all the particulars had to make three identical statements. They also had to be unimpeachable. Testimony from a single eyewitness was insufficient for a capital sentence. Written proof was adequate in certain cases such as forgery if the accused admitted writing the document. Hearsay and indirect evidence were considered 'proximate indications,' which could not lead directly to a conviction. They could, however, justify torture to extract a confession, which would then constitute a complete proof. 'Remote indications', such as the attitude of the accused when questioned, were not given much weight... 10 When the necessary conditions to prove guilt were met, judges could choose from over twenty different types of punishment clearly specified in the Criminal Ordinance of 1670. Penalties included death, torture, perpetual service in the king's galleys, permanent banishment, service aboard the galleys, the lash, branding, the amende honorable (publicly asking forgiveness), banishment, and fines. Since there were no prescribed penalties for specific crimes, judges had considerable discretion to take into consideration circumstances of the crime and the defendant's social position. Three judges were required to sentence an accused to corporal punishment and the most lenient opinion of the three always prevailed. To dissuade others from committing crimes, punishment was exemplary and meted out in an elaborate public ritual that was in itself a political statement designed to reinforce the power of the state. None but the king, by virtue of divine right, could exact vengeance for a wrong or grant pardon."

${ }^{20} \mathrm{BC}$ Campus, $\underline{\mathrm{https}: / / \text { opentextbc.ca/preconfederation/chapter/4-6-canada-1663-1763/ }}$ 
Coutume de Paris the law of the colony. (Dickinson, p. 38) "Codified in 1580, this fairly comprehensive body of legal rules governed property and family law. With its medieval origins, it had less to say about commercial law, relations between masters and servants, and community obligations regulated ad hoc by royal edicts and ordinances." (Dickinson) Furthermore with French Law heavily influenced by the Napoleonic Code which in turn drew from Roman Law, "Roman law could also be used where customary law was inadequate, but its authority was only moral, and judges could opt for the application of another custom." (Dickinson)

The Coutume de Paris reflected the social concerns of the sixteenth century France, and it sought to "reinforce a system based on the patriarchal family." (Dickinson, p. 39) 22 And, although Roman law was taught in French universities after 1679 and considered the "mother" of all legal systems, it had a limited influence on magistrates because customary law incorporated different assumptions, particularly in the colonies, especially regarding property and family. (Dickinson) $)^{23}$ It is indeed difficult to believe that,

"far from the constraints that the proponents of the written law placed on the use in France, it (or rather these because of the composite nature of emigration) was not going to resurface on the new soil offered to it America? This would be born, alongside what I would call, since they are written, of local 'customs' imported by each of the emigrants according to their place of departure and a 'custom' imposed by the monarchy for the sake of efficiency, a (true) custom what could then be described as Acadian. Once again these are impressions that only the study will disprove or confirm."

(Vanderlinden 1996: p. 31)

The example of aboiteaux ${ }^{24}$ is used to demonstrate how a codification of French property did not fit in Acadie, where using labor intensive techniques the Acadian settlers converted tidal marshlands adjacent to the Bay of Fundy in fertile farmland by constructing a system of earthen dykes to prevent the sea from submerging the low lying adjacent lands.(Caron, pp. 5-6) These lands were effective man-made working agricultural lands that held an entirely different cha-

\footnotetext{
21“'Only Montréal's seigneurial court was abolished when transformed into a royal court in 1693. Although royal jurisdictions in each government (the St. Lawrence colony was divided into three administrative districts called governments) and an appellate jurisdiction for the colony were clearly necessary, the creation of an admiralty court at Québec in 1719, came as much from the intendant's desire for new patronage positions as from a need to resolve maritime disputes."

22“"The patriarchal family was the basis of ancien régime social order and the Coutume sought to insure the husband's marital authority and the integrity of patrimonial lands and chattels. All marriages were regulated by the communauté de biens unless otherwise specified in a marriage contract. Property possessed before marriage or obtained through inheritance remained personal (propre)." ${ }^{23}$ Id. "The Coutume de Paris was divided into sixteen titles (the short twelfth title was not operative in New France); six concerned family and inheritance (titles 7, 10,11,13, 14 and 15), five concerned property $(1,2,3,4$, and 9$)$ and four dealt with debt recovery $(5,6,8$ and 16)."

24" From Canadian French aboteau, aboiteau, apparently ultimately from Middle French bot elevated bank of a canal, dyke + -eau, suffix, probably via a French regional (western) intermediary." https://www.lexico.com/definition/aboiteau
} 
racteristic than the lands of France covered under its property laws.

"This is a new practice, which certainly has equivalents in the salt marsh technique on the French Atlantic Coast, but the written customs of Aunis, Poitou or Saintonge do not refer to it. The place is therefore free to create a custom relating to rights on land resulting from this 'clearing' of the sea. While the authors do not shed much light on us (none of the authors cited give its sources on this point and the question remains open) on how the meadows resulting from the joint work were distributed, Cormier is clearer when dealing with the construction and maintenance of the and writes that each must contribute to this work and, in case of prevention is required to provide monetary compensation. Isn't that a custom? It remains to be determined its legal character and therefore how it imposed itself on the inhabitants. I am convinced that this is not the only opportunity to see the birth of other 'true' customs of Acadian social experience." (Vanderlinden, 1996: p. 32)

Drawing further from the New France legal framework, the analysis of the acts of the legal and administrative practice clearly shows that it differs from place to place. "The study of marriage contracts in Port-Royal, Royal Island and St. John's Island reveals significant differences between these three locations. And it is likely that an extension of the comparison to Quebec would reveal new differences" (Vanderlinden, 1996: p. 33). Nevertheless, there are also traces of direct application of the "custom" of Paris in Acadia, e.g. "the formalities prescribed for the validity of an official will (art. 289 of the reformed custom of Paris of 1580) or of the lineage withdrawal (art. 129 of the same custom)" (Vanderlinden, 1996). While these are observed as Acadian custom during the English period of rule, there is little reason to believe "that the 'custom' invoked at that time was not, if any, during the French period" (Vanderlinden, 1996).

In 1664, when Louis XIV promulgated the Édit portant établissement de la Compagnie des Indes occidentales, Acadia was still a possession of the English crown. This édit (edict) was represented "the fundamental law of New France, of which Canada was part with Louisiana, Terre-Neuve (Newfoundland) and the Île Royale (the Cape Breton Island of today)" (Vanderlinden, 2019: p. 37). Given British occupation and rule of Acadia at the time of the French crown's edict, it was "thus never formally promulgated in Acadia, though the territory was de facto considered as part of New France" (Vanderlinden, 2019). ${ }^{25}$ Despite the geo-political conflict and challenges of the last period of French rule in Acadia 25 "However, how much were its administrators (not to mention its population) fully conscious of its contents is another story. The more so, the French administrators disembarked in the province coming directly from France. A word finally about the position of the Amerindians in this setting. Their position was clear as all evidence shows. From their point of view, the Algonquins, Malecite, and Micmawks living in Acadia simply at home and tolerating the French colonists as long as they were useful and not a nuisance. No treaty was ever signed by any of these ethnic groups with France. There never was any conquest of their territory, which could have led to a transfer of territory. Thus, from the European point of view, there may be no justification of French sovereignty over the territory, if one refers to the public international law of the times." 
(Vanderlinden, 2019) ${ }^{26}$, jurists have;

"a reasonable amount of evidence regarding the complexity of jurisdictional orders in the region. It challenges the wording of article 34 of the abovementioned Édit. The judges established in these places will be bound to judge in accordance with the laws and ordinances of the Kingdom, and the Officers to follow and conform themselves to the Custom of Paris, following which the inhabitants will be able to contract without being allowed to introduce any other custom in order to avoid diversity." (Vanderlinden, 2019)

The year 1667 represents a significant time in the history of source law in France. "It presents 'the promulgation of the first of the grandes ordonnances characterizing the reign of Louis ('L'Etat '́ 'est moi') the 14th bearing this first name" (Vanderlinden, 2019: p. 35). It's also when France reassumed, through the Treaty of Breda, its power on what was then known as Acadia; which had been conquered by New England colonists in 1654 (Vanderlinden, 2019). As a result, from 1667 to 1710, in principle, Acadia lived under French rule. Subsequently, in 1688, under French rule, 'the first royal judge was appointed, followed by a notary, and a procureur representing the king in legal matters' (Vanderlinden, 2019, pp. 35-36) ${ }^{27}$. Also in 1677 the French crown 'appointed a Prévôt de la maréchaussée. In France these officials had important functions in repressing banditry and vagrancy. They summarily judged, without appeal, crimes committed by vagrants and the military.' (Dickinson, p. 38) Whereas, in New France such cases were judged by the Sovereign Council (Dickinson, pp. 46-47) ${ }^{28}$, so the Prévôt's principal function was narrowed to search and arrest of criminals and deserters. (Dickinson) It has also been learned from the Judgments and Deliberations of the Sovereign Council of New France, that it was "unusual for the Council to have an issue of interest to Acadia" (Vanderlinden, 1996: p. 3)..$^{29}$

While the evolution of laws and administration of colonial life in Acadia and New France was under conflict as sovereignty swung in balance during the period between France (Civil Law) and Britain plus New England (Common Law) it can therefore be considered that during the French rule, post 1667 proclama-

${ }^{26}$ See also D.G. Bell, at 117-118. "Under the ancien régime the disjuncture between theory and practice, and the toleration of the unsystematic and anomalous, were often startling. The ad hoc and inefficient multiplicity of superior court jurisdictions noted earlier exemplified this, as did the great discrepancy between the number of felons sentenced to death and the number actually hanged. Oath requirements barred New Brunswick's Roman Catholics, in theory, from participation in any branch of public life; yet in practice they held commissions as both magistrates and militia officers."

${ }^{27} \mathrm{P}$. 35-36, "There were also indications of the existence of a lieutenant général. As we shall show later, we do not know much regarding the lieutenant général and even less in his assumed capacities as a judge."

${ }^{28}$ P. 46-47. Early New France colonial society at this time is described as feudal. "The existing external structures look feudal indeed in official documents of the King's Council in Versailles, up to the early years of the $18^{\text {th }}$ century... Rights of high, middle and low justice were also conferred subject to appeal to either the Conseil Souverain of the court of prévoté in Quebec City."

29 “'Although he registered Meneval's appointment as governor of the region in 1687 and Goutin's appointment as Lieutenant General in 1688, the same was not true of their predecessors or successors; ... clearly Acadian affairs are not the first concern of the authorities of New France." 
tion there was;

"a uniformity of the legal system throughout New France and that the conclusions that can be drawn for the centre are also valid for the periphery. Let me doubt that. The most rudimentary attendance (this is the level of mine) of the sources of law in Acadia during the French period clearly indicates that the problems could not be solved as in Canada. The origin of the populations, the administrative and judicial organization, the establishment of the clergy, the agricultural practices of the inhabitants are different, while society itself seems to have remained much more a society of the oral than on the shores of the St. Lawrence; in short, it is difficult to imagine that such dissimilar conditions could produce an identical right. One of my ambitions is precisely to show that there is indeed a right specific to Acadia, even during the French period. (Vanderlinden, 1996)

Also, as per Exhibit 1 presented earlier in this paper, as of 1670, there was a succession of "provincial" governors appointed by the French Crown for Acadia. However, their primary functions were notably military. As well, their location in Port Royal, on the south-western or far western border of Nova Scotia "faced the English possessions of New England, which considerably reduced their administrative capacities; especially since two of them spent a good deal of their term of office as prisoners in Boston after being defeated by the New Englanders" (Vanderlinden, 2019: p. 36). Furthermore, the situation while unstable was climaxed in 1710 by the "everlasting fall of Port Royal." (Vanderlinden, 2019).

The long period between the fall of Port-Royal in 1710 and Britain's concession of responsible government to its remaining American colonies in the $1840 \mathrm{~s}$ (to what today are known as Canada's Maritime Provinces) "presents a sometimes-bewildering spectacle of war, treaty, experiment and reformation" (Bell, 1996: p. 103).

"In 1710 Acadie/Nova Scotia was still a fault line between clashing French and British empires; its European inhabitants consisted only of 2000 Acadians settled on the shores of the Bay of Fundy and governed by the law of military occupation. A long century later the region's half million people were divided amongst three self-consciously loyal British colonies pioneering a constitution under which elected representatives of the people were the dominant influence in government." (Bell)

In 1713, the year of the signing of the Treaty of Utrecht transferring Acadia from France to Great Britain, "left present-day New Brunswick in dispute between the two countries and kept Saint John Island (now Prince Edward Island) and Royal Island, now known as Cape Breton Island, in dispute.” (Caron, p. 7) Today the Maritime Provinces of Canada (New Brunswick, Nova Scotia and Prince Edward Island) and also known as the Atlantic Provinces when Newfoundland which was last to join Canada in 1949, is added, are often mistaken to have had similar histories. "However, these were the years in which Nova Scotia, 
Prince Edward Island and New Brunswick were most distinct demographically and in political culture. Particularities were significant even within individual colonies, as geographical isolation permitted settlement groups to retain old world ethnicities." (Bell, p. 103) And it should be noted though despite "diversities of terrain and people, however, the legal institutions of the Maritime colonies in their formative era were markedly similar." (Bell) Upon conquest and under British rule, while still under military rule, (Bell, pp. 105-106) ${ }^{30}$ the groundwork for the implementation of permanent settlement, institutions and a common law system began..$^{31}$ (Bell)

Upon conquest and under British rule, while still under military rule, the groundwork for the implementation of permanent settlement, institutions and a common law system began.

"Constitutional arrangements imposed by the imperial government addressed one obsessive concern: how were the colonies to be retained within the empire, safeguarded from both internal rebellion and French or American conquest? This perceived need to bolster colonial 'loyalty' was the grand premise from which all subsidiary features of the colonial constitution theoretically derived. Hence, despite particularities of terrain and peoples, most of the colonies remaining to Britain after the American Revolution were alike in structure of government. Moreover, whatever the formal machinery, all pre-democratic colonial regimes faced similar domestic challenges: how to maintain civil peace in a society without police or even the discipline of common schooling, when large numbers of subjects, notably Roman Catholics, aboriginal peoples. and women, were virtually barred from voting and holding public office? How to bring the machinery of civil and criminal justice out from the colonial capital into the hinterland? How to administer localities in the absence of village or county councils? how to conduct the ordinary legal transactions of life, such as deeding land, selling slaves, collecting debts and settling property on offspring, when most people lived far from a lawyer? How to foster an honourable and learned' legal profession?" (Bell, p. 103)

Upon conquest Acadia remained under the long historical periodic shadow of military threat and whereas Britain was only a little more than a century from its glorious Protestant rebellion and attack on Catholicism, the Acadians not only ${ }^{30} \mathrm{Id}, 105-106$. "The British conquest of 1710 left them under what in constitutional terms was a sort of military dictatorship. Under this régime, centred initially on the fort at Annapolis Royal, military officers ruled Nova Scotia as both governors and judges for a half century, without benefit of representative institutions or common lawyers."

31"Although England had a claim in international law to lands which became the Maritime provinces based on fifteenth-century 'discoveries' by Giovanni Caboto, it was not until the French capitulation at Port-Royal on 2 October 1710, confirmed by the Treaty of Utrecht (1713), that the peninsular part of what is now Nova Scotia came under permanent British rule. It was a further half century before France surrendered the rest of Acadie, including present Prince Edward Island, Cape Breton and New Brunswick, by the Treaty of Paris (1763). Throughout most of the 1710-60 period the British conquerors were in the awkward position of ruling a colony populated solely by Acadian and Native peoples, both allied sympathetically and often actively with France.” 
represented a heritage of French rivalry but also a colonial population of Catholics. As such for the British, there could be no question of an elected legislature for Acadia until such time as the colony would be re-populated with Protestants. During the beginning of British rule of Acadia, governance was carried on through decrees of the Governor and his council;

"but an informal system evolved in which the British communicated their grand concerns to the populace through Acadian 'deputies,' elected annually on the king's birthday. Acadian notaires recorded marriage contracts, land transactions and other legal incidentals of daily life, while government so far ignored religious impediments as to make at least one Acadian a justice of the peace. All of the few crimes to come before the colony's only judiciary, the governor and council sitting as a common law court, were tried as misdemeanors, because the number of "gentlemen" required at common law for convening a grand jury put trial of felonies beyond practicality. Civil disputes among Acadians, when not settled informally by priests, elders and the deputies, were handled by this Court of Governor and Council with sometimes surprising subtlety. It willingly adjudged property and succession disputes by resort to what it knew of the tenets of the droit civil. In complicated matters this might be bolstered by drawing on Acadian oral tradition for understanding, or misunderstanding, of the relevant coutume, as when in deciding a 1732 property dispute the court enquired of Prudent Robichaud 'What the Custom of the French Inhabitants was in Such Cases,' and then gave judgment accordingly." (Bell, 105-106)

Although Acadia's Governors under British rule provided its French-speaking subjects with legal necessities, the military succession at Annapolis (Port Royal) didn't win the allegiance of Acadians; (Bell) "32 "and as long as mistrusted Acadians and Natives dominated Nova Scotia," (Bell) $)^{33}$ and the influence of this "mock Government" failed to extend "beyond cannon reach of the fort, the British could never attract protestant settlers to counterbalance their influence." $(\text { Bell })^{34}$ Rather, it was only after deportation of most Acadians, and the seizure of their fertile lands, "beginning in 1755, the fall of Québec in 1759, and formal surrender of France's empire in North America in the peace of 1763, was the colony secure enough to attract northward thousands of New Englanders to vacated Acadian farms and convenient fishing ports." (Bell) This re-settlement of British Loyalists from New England to Nova Scotia represented "a new beginning, the constitutional capstone of which was the convening of an elected House of Assembly in 1758, the first in what is now Canada." (Bell) ${ }^{35}$

After the Acadian expulsion by the British began, several large waves of New

32“[T] $]$ he attempt to adapt the machinery of a large empire to the government of a small colony present [s] many objects for ridicule or satire. [Haliburton, Old Judge, iv]." ${ }^{33} \mathrm{Id}$

34"Not even the founding of Halifax in 1749 as the new colonial capital and counterweight to Louisbourg altered the equation decisively." 
Englanders immigrants arrived in the 1760s to the end of the century, to take up farms that had been cleared and developed for agriculture by the Acadians. (Bell, pp. 107-109) Of the other settlers received during this period in the region formerly known as Acadia, the most numerous were Scots, who settled Prince Edward Island, Cape Breton Island "and the Northumberland Strait shores of the mainland, and American Loyalists, the largest number of whom settled at Shelburne and in the St John, St Croix and Annapolis river valleys. Even Acadians were allowed to return after the peace of 1763 , although now consigned to the region's geographical margins." (Bell)

The arrival of English protestant settlers and a heightened attention by Britain directed to its North American colonies (Bell, pp. 117-118) following its loss in the American Revolutionary war (also known as the American War of Independence, 1775-83) (MyRevolutionaryWar.com) triggered a general reorganization of the region. "In 1769 Prince Edward Island was separated from Nova Scotia; the erection of New Brunswick and Cape Breton as distinct colonies followed in $1784 .^{10}$ The structure of colonial government emerging from the 1780 s was the one that endured until the peaceful revolution of the 1840s." (Bell, pp. 107-109) Essentially, by providing the Maritime colonies with their own respective colonial charters, the British crown's objective was to circumvent the spreading of colonial independence arising in the United States from setting root in the Maritimes (Bell, p. 108) ${ }^{36}$. This British administrative trend of entrenching its remaining British North American holdings extended subsequently in 1867 to the union of Upper Canada, Lower Canada (Quebec), New Brunswick and Nova Scotia (which had annexed Cape Breton in 1820 (Bell) ${ }^{37}$. Under these colonial constitutional arrangements, "although London foreswore its general right to legislate directly the internal affairs of colonies with an elected assembly, nonetheless the colonial constitution weighed heavily towards the appointed executive rather than the partly elected legislative branch." (Bell, pp. 107-109) For instance, from 1786 forward the remaining British North American colonies were:

"in theory ruled by a governor-general, headquartered at Québec, whose local deputies within individual colonies had the status of lieute-

35"With inauguration of representative institutions, Nova Scotia's predicament as a 'Military and almost an Arbitrary Government' began to meliorate. ${ }^{6}$ Yet for many reasons, notably two wars with the Americans and four with France, all between 1775 and 1815, the military continued a highly visible presence in the region until well into the nineteenth century."

36"In eighteenth-century America the terms 'colony' and 'province' were used interchangeably, although the latter prevailed in formal contexts. In the first half of the nineteenth century colony became the prevailing usage, supplanted by province only after Confederation. By the mid-nineteenth century, when writers felt the need to refer to the three colonies as a collective, the term 'Lower Provinces' came into use. It was probably about that time, also, that the 'Maritime' terminology began, but the rise to popularity of that expression has apparently never been investigated."

${ }^{37}$ During the period of its separation from Nova Scotia as its own colony, 1784-1820 "Cape Breton was never granted an elected assembly; laws were framed as ordinances of lieutenant-governor and council. Although the colony was given a Supreme Court, a General Sessions of the Peace and an Inferior Court of Common Pleas, little is known of how the legal machine ran in practice. After Chief Justice Archibald Dodd ruled that a number of Cape Breton's ordinances were invalid and cast doubt on the lawfulness of the remainder, the colony was, in 1820, re-annexed to Nova Scotia." 
nant-governors. These lieutenant-governors, chosen from London and almost always Britons rather than colonials, were the centerpiece of colonial administration, so much so that in the Maritime colonies they acted without much reference to their nominal superior at Québec. All major and many lesser officials, from chief justice down to justice of the peace, were appointed either by the lieutenant-governor or directly by London. The lieutenant-governor headed the militia, presided over the highest court, and had access to sufficient 'casual and territorial' revenues to run government, if need be, without co-operation from the legislature. Assisting the governor in executive functions was a council, its members named by London on the governor's advice. It functioned more like a privy council than a cabinet, in the sense that there was no requirement that the great officers of administration, such as the provincial secretary and attorney-general, be members; and there was no principle of collective responsibility. When the colonial legislature, styled the General Assembly, was in session this Council doubled as the upper legislative chamber. No measure could become law unless it had passed both the elected House of Assembly and the appointed Council sitting in its parliamentary capacity and then received the governor's approval. Over internal affairs of the colony, the jurisdiction of the General Assembly was practically supreme, though London reserved to itself trade, defence, foreign affairs and related matters." (Bell, p. 107)

As Britain laid its colonial institutional foundation within its conquered New France domains, "post-exilic Acadians shunned the alien values of their conqueror's legal system, instead submitting disputes to resolution by elders and priests." (Bell) Another event seen as the early beginnings of Britain's founding of Canada, is with the passing of the Quebec Act in 1774 (Laforest, 2016). Similarly, faced with a major threat from American colonies, Great Britain abandoned its policy of assimilating its new subjects of French descent and Catholic faith $^{38}$. "The earlier promise concerning the establishment of a legislative assembly was taken away, but replaced by many concessions on the identity front: religious relaxations for Catholics and recognition of the French civil law." ${ }^{39}$ Subsequently, 17 years later, Upper Canada and Lower Canada (Quebec) were merged 38 "Within two generations, the French settlers in the St. Lawrence Valley had become 'Canadianized, blending their European heritage with traits borrowed from the Aboriginal world. Aware that they enjoyed far more freedom than their counterparts in France, they referred to themselves as habitants rather than paysans. Driven by a spirit of egalitarianism, they usually proved resistant to hierarchy. They were commonly called 'Canadians' to distinguish them from French sojourners in the colony who had not joined settler society. The colonial authorities, civilian, military and religious alike complained regularly of the rebellious spirit of the Canadians.”

https://www.elections.ca/content.aspx?section=res\&dir=his\&document=chap1\&lang=e ${ }^{39}$ Id.

40" Ironically, unifying the two Crown colonies produced the exact opposite effect: rather than forcing the French-Canadians in the former Lower Canada, or Canada East, to assimilate into English-speaking culture, the United Province of Canada necessitated a political culture of consociationalism ${ }^{40}$ and elite accommodation between equivalent English and French-speaking political parties and even produced a dual or co-premiership, with one English-speaker and one French-speaker heading each Ministry." 
through the Constitution Act of 1791, and each were endowed with a legislative assembly. (Bell, p. 29) ${ }^{40}$ However, the first legislative assembly in Canada was established in Nova Scotia in 1758 (ElectionsNB) and 1773 in Prince Edward Island, (PEI) and granted to New Brunswick (ElectionsNB) and Cape Breton in 1784 (Cape Breton, 2017). ${ }^{41}$

Eighteenth-century Prince Edward Island (former pre-conquest French colony named Ile St. Jean) "shared early Nova Scotia's predicament as a small, obscure colony in judicial infancy, but this condition persisted longer." (Bell, p. 122) For instance, from 1769 to 1824, there was no resident jurist on the Island trained in English law, (Bell) ${ }^{42}$ and the state of legal system during this period in Prince Edward Island, as J.M. Bumsted in his historiographical essay, maintains P.E.I. tends to be, "parochial in nature and exceptionalist in interpretation." (Brown) Albeit limited legal documents are available from this period, a dominate issue gleaned from historical research identifies a primary issue with "the bitter land question on P.E.I. that started when the British divided most of the island into sixty-seven lots, and handed the properties to wealthy landlords." (Brown). Part Two of Bumsteds essay contains three articles examining "The Administration of Justice." His overview of the justice system of P.E.I. from 1769 to 1805 , demonstrates "the early justice system was highly politicized." (Brown)

"Leading landholders and politicians (who were often the same) attempted to employ the justice system to settle their personal disputes, a problematic tendency since the legal system lacked expertise and law and politics often intermixed. He concludes that the justice 'was not meted out fairly,' (72) and suggests that the use of the justice system for personal vendettas 'was probably more pronounced on the Island than in any other jurisdiction in early British America.' ... Part Five, 'Litigation in Chancery and at Common Law,' includes detailed case studies of two infamous cases. In the first study, David M. Bulgar examines Bowley v. Cambridge, a P.E.I. equity case litigated for forty-seven years. Like Bumsted, Bulgar shows that the P.E.I. justice system was marred by intrusive actions by the island's small colonial elite and was slowed by the lack of trained legal personnel. For Bulgar, the case stands as an example of how the problems of Chancery practice led to delay and expense for the parties. According to Bulgar, the complexity of Chancery 'actually defeated justice.' ... A fourth theme is that concerns

${ }^{41}$ Cape Breton. although granted a legislature, was never permitted, albeit not for lack of trying, to call an election and hold its legislature. "The people of Cape Breton were thus denied the right to vote for 57 years - from 1763 to 1820 - an unenviable record for a British North American colony." https://www.elections.ca/content.aspx?section=res\&dir=his\&document=chap1\&lang=e

${ }^{42}$ 'The only members of the judiciary to give promise of competence, Thomas Cochran and Robert Thorp, were soon promoted to the marginally less primitive Upper Canada. The longer-tenured chief justices, Peter Stewart, Caesar Colclough and Thomas Tremlett, squandered their modest usefulness by miring themselves in local politics ... In 1798 it was complained that: "if it should so happen that a jury, more inclined to do justice than our Chief Justice [Stewart], should give a verdict to one obnoxious to the [governor's] party, the case is immediately hung up in Chancery, the Governor being Chancellor, where the known partiality, and great expense of the court, frighten them from justice." 
about access to justice were often expressed in both jurisdictions. As Goudie and Bumsted show in Newfoundland and P.E.I. respectively, inhabitants consistently called for the retention or creation of decision-making bodies that could cheaply and regularly serve communities outside of Charlottetown and St. John's." (Brown)

A judge in Acadia (like France at the time) "was a styled lieutenant and had a double jurisdiction: civil and criminal; hence, the title lieutenant general (lieutenant général) which combines the functions of lieutenant civil and lieutenant criminel" (Vanderlinden, 2019: p. 39). Notably, the court system is Acadia was devoid of judicial circuits, and meeting the judge involved a long and expensive journey (Vanderlinden, 2019: p. 40) as coastal communities were spread out over long distances in Acadia. "Furthermore, this made appeals to the Conseil souverain of New France (situated in Quebec City) practically impossible" (Vanderlinden, 2019). Further details on civil and criminal legal procedures in Acadia are unfortunately limited legal papers cite an absence of court records for Acadia during the French period (Vanderlinden, 2019: pp. 41-42).

"whatsoever for Acadia during the French period. At least two factors explain this unfortunate situation. First, the destruction of all existing archives with the burning of the registrar's house, a well-documented event. Jean-Chrysostome Loppinot, who was also appointed by the Crown as notary public, was a man of distinction in the small local community of Port-Royal and, as, he lived in the fashionable neighbourhood overlooking the rivière au Dauphin next to the fort. No wonder that in one of the numerous attacks on Port-Royal, his house was destroyed by fire as a result of a cannonade originating from English ships. This caused the loss of the notary's and registrar's archives and practically all direct sources on Acadian legal history during the French period. Second, the care of official documents was not entrusted to a specific department in what was the skeletal administration of Acadia. When, in 1710, French officials, including the lieutenant civil et criminel and the notary-registrar, left Port-Royal for good with the vanquished French garrison, the documents entrusted to their care either accompanied them or were abandoned to the next occupant of their respective quarters. What happened to them is unknown" (Vanderlinden, 2019: pp. 41-42).

The British conquest of New France produced a military regime lasting from 1759 to 1764, and for a decade afterward "confusion reigned among legal men on both sides of the Atlantic as to how much, if any, English civil law had been forced upon the new colony of Quebec by the Royal Proclamation of 1763" (Greenwood, 1996: p. 133). For a multitude of political reasons, including a "policy of conciliating the newly conquered 'Canadiens'," (Greenwood) fifteen years after the British conquest of New France, made permanent by the Treaty of Paris (10 February 1763) the imperial parliament restored the "Canadien" civil 
laws of Lower Canada (the Quebec Act of 1774), which represented "an unwieldy mass which would continually grow more confusing until codified in 1865-66." (Greenwood, p. 132)

This restored the French civil system (Greenwood, p.133-134) ${ }^{43}$ :

“... in all Matters of Controversy, relative to Property and Civil Rights, Resort shall be had to the Laws of Canada, as the Rule for the Decision of the same. 2 Restoration included all regulations applying to the feudal or seigneurial system of land tenure (e.g., the seigneur's banalité or monopoly of gristmill, whereby habitant farmers were obliged to grind grain needed for domestic consumption at the banal mill, paying 1/14th for the service). What then were the laws of Canada (or New France)? No one in 1774 could have said with any precision. Sources were multiple, often overlapping, sometimes contradictory. The main source was the Coutume de Paris, the century-old basis for the New France civil law confirmed by Louis XIV in 1664. These were the laws governing Paris and adjacent regions, dating back at least to the early middle ages. The Coutume had been codified into articles during the sixteenth century and published in 1580; but it apparently required several tomes of scholarship thereafter to approach clear meaning. 3 In addition to the skeletal and sometimes obscure Coutume de Paris, the Canadien laws included significant portions of Roman law (e.g., on contracts) and canon law (e.g., on marriage); a few rules drawn from other coutumes; judgments of the courts in France and in Canada, particularly those of the highest colonial court, the Sovereign/Superior Council; and, legislation of the governors and intendants and royal edicts applying to the colony." (Greenwood)

The evolution of Canadien civil law was also heavily impacted by the French Revolution, which began in 1789, (Greenwood, p.144) because its influence extended beyond France's borders, and particularly after war commenced between Great Britain and France in 1793. (Greenwood)

Between late 1792 and 1797, the bourgeois alliance in Quebec of anglophone and francophone reformers died. Many forces were at work: the lesser need for allies now felt by Canadien politicians, the ultra-conservative attitudes of pre-industrial farmer-electors and the gradual demise of Canadiens engaged in import-export commerce. One development of prime importance was the shattering impact of the French Revolution on the psyche of the English minority, outnumbered by about 15-1, referred as a "garrison mentality." (Greenwood)

43"Arguably part of the colony's legal system were the ordinances enacted by the Bourbon kings for France. In the mother country, ordinances did not come into force in any region unless registered by its highest court (parlement). None of the ordinances, e.g., dealing with donations, civil procedure and commercial transactions, was registered by the Sovereign/Superior Council, although the colonial courts enforced most if not all. After the Conquest of 1760 the question arose as to validity of the unregistered Code Marchand, 1673, a set of rules facilitating commerce (e.g., regulating negotiable paper, protecting creditors of a bankrupt), on which the courts and lawyers divided. Added to these sources of law would be provisions contained in local and imperial legislation and the writings of a few local lawyers, concerning 'la doctrine' and the works of pre-Revolutionary French scholars." 
The breakdown of cooperation between British and French merchants and ruling class, meant that politics going forward became split largely along ethnic lines. For instance, "there could no longer be a bi-ethnic force to liberalise the constitution, such as, by establishing an independent judiciary." (Greenwood) This breakdown in the bourgeois alliance of New France made "the 'parti Canadien' becoming far less interested in commercialising the law and much more prone to protect traditional Canadien laws and customs." (Greenwood, p. 145) ${ }^{44}$

At the root of French law in the eighteenth century, societal values embraced include three categories: "equity in contracts, the link of the family to its often traditional lands, and fair protection for vulnerable members of the family." (Greenwood, p.135) Concepts of equity in the contractual realm during the period included "usury laws against excessive interest on loans and provisions for protection of debtors: for example, the requirement of formal written proof of debts exceeding 100 livres (about $\mathfrak{£} 5$ sterling) and the short prescriptions to collect for wholesale and retail sales, of twelve and six months respectively." (Greenwood) Furthermore the legal concept of lesion (Greenwood, pp. 135-137) ${ }^{45}$, was a distinguishing feature compared to contemporary English and later Quebec law. Another distinguishing feature was the retention of family real estate within a family. (Greenwood) ${ }^{46}$

"Thought to foster an ordered society, it reflected the aristocratic and gentry desire to exhibit ancient lineage. The Coutume was full of rules helping to preserve a family's link to its lands. Spouses, for example, could not inherit from or make contracts with each other after marriage. Sale of a seigneury required payment of a fine of one-fifth the price to the crown. A second rule aimed at discouraging land speculation established mutation fines of one-twelfth the price (lods et ventes), payable by the buyer to the seigneur, when roture (granted) land was sold to non-family members."

(Greenwood)

The Quebec civil system during the period was evolving from many influences including pressures to angelize and adapt to common law. Drawing from its French traditions and culture its civil law sources were "1) In the main, Quebec followed the Custom of Paris which had been introduced in Canada in 1664; all other customs had been forbidden. 29 But, out of the 326 articles of the Custom of Paris, 125 were not law in Lower Canada when codification was ordered"'

\footnotetext{
44"By the early months of 1805 , then, the parti canadien had become defensive, indeed rigid in protecting the traditional laws, which were referred to by Bédard and his followers as a well-constructed 'édifice,' articulating the wisdom of the forefathers and to be kept almost entirely intact. 'Legislative paralysis' had begun, dooming for a generation any significant amendments to the civil law."

45"In theory (i.e., it seems to have been of little practical importance), an injured party in certain real estate contracts, such as sale, purchase, exchange and physical partition between co-proprietors (e.g., co-heirs) could nullify the agreement if he or she had made an extremely bad bargain. Pothier explained the rationale thus: when rough equality was not achieved "and one of the contracting parties gives [much] more than he receives, the contract is void, because it sins against equity, which must govern."

${ }^{46} \mathrm{Id}$. "An absolutely crucial motive de Ferrière claimed in French law."
} 
(Greenwood, p.133) 2) the Ordinances of the Kings of France, (Fabre-Surveyer, 1939, p. 655) 3) The Code Napoleon, (Fabre-Surveyer, p.657) ${ }^{47}$ 4) French commentaries and decisions ...

"In 1871, Honorable E. T. Merrick, late Chief Justice of the Supreme Court of Louisiana, said: a ... although the French laws are esteemed foreign laws which require to be proven when brought in controversy in our courts, yet the similarity of the French text of our late codes to the Napoleon code has been so great, that commentators on the French code, as well as the decisions of the court of cassation, have exercised great influence on controversies arising under our own code. Perhaps one reason has been that we have no commentaries of our own further than some annotated codes, and a work on criminal law and digests of the decisions of the courts, owing to the limited sale which has followed all similar publications. Hence French authors are an essential part of a lawyer's library." (Fabre-Surveyer, pp. 657-658)

Other sources of Quebec law include Priests (e) and (f) The Seigneur, the French scholars of the 19th century. (Vanderlinden, 2019: pp. 46-47)

"Catholic missionaries or priests played an important role in colonial French North America. Acadia was not an exception on this matter. From our point of view, they were the most important because they had a quasi-monopoly on legal matters affecting marriage. They also exercised a nearly constant control over the daily life of their parishioners; this went to the point that one occasionally found in Acadia." (Vanderlinden, 2019: p. 44)

The diversity of the sources of French civil law (Laidler, 2005: p. 278) as well as elements of Scottish civil law representing the training of English speaking Scottish attorneys appointed by the British to the bench and administrative executive positions in New France, the diversity of languages French versus English, (as well to a much lesser extent Scots Gaelic) in which it was expressed, along with an "absence of contemporary commentaries on that law and strong position of the French code (Laidler), resulted in pressure for codification which led to the formation of a commission in 1857," (Laidler) founded by Quebec's Attorney General George-Éteinne Cartier. (Laidler)

As Goldwin Smith asserted, 'if 'deadlock' was the real father of Confederation, ... then chaos sired codification, with Cartier the persevering, far-sighted midwife." (Greenwood, para. 75)

\footnotetext{
47 “... it goes without saying that both Louisiana and Quebec owe a great deal to the Code Napoleon. Whether or not the Code of Louisiana was based on the first draft of the French Code, 'there is no doubt that the Louisiana work differs from the French in a great many respects, due to the incorporation of Spanish law. It is also different in form, since it comprises over a thousand more articles,' a great many of which contain definitions and explanations which in France are found in textbooks. In Quebec, on the other hand, the framers of the Code were instructed to adhere closely to the form of the Code Napoleon, and the law provided: "The said Code (s) shall be framed upon the same general plan, and shall contain, as nearly as may be found convenient, the like amount of detail upon each subject, as the French Code (s)."
} 
"Confusion deriving from the multiplicity of often contradictory sources of law and the ignorance of and purposeful anglification by the English judges had characterised the civil law since its restoration in 1774. As time passed the problem worsened with the growth of statute and case law, the latter communicated to the profession mainly through hearsay until the inauguration of the Lower Canada Reports in 1850." (Laidler) ${ }^{48}$

From 1774 to 1866 Quebec's civil law, represented a much contested battlefield of clashing cultures and legal systems rich in historical meaning, that underwent profound change during the period,

"sloughing off older concerns grounded in feudal and Roman Catholic morality, so as to promote autonomous individual will, particularly in areas impinging on commerce. Many rules aimed at preserving the linkage of the family to its lands were repealed; legally enforceable equity in contracts disappeared; the married woman was empowered to renounce customary dower, and gifts as well as testaments were freed from familial constraints." $(\text { Laidler })^{49}$

Lord Durham, Governor and Royal Commissioner in 1838-39, in his famous report stated:

"The law of the Province and the administration of justice are, in fact, a patch-work of the results of the interference ... of different legislative powers, each proceeding ... utterly regardless of the other. The law ... is a mass of incoherent and conflicting laws, part French, part English, and with the line between each very confusedly drawn ... The French law of evidence prevails in all civil matters, with a spec exception of 'commercial' cases ... but no two lawyers agree in their definition of 'commercial."”50

Thus codification of Quebec law was in large part pursued to provide consistency within its rules by eliminating hundreds of situations where due to overlapping and confusing laws it was "anybody's guess." (Greenwood, para. 75) The other important purpose behind codification was to translate the civil law, "since as the preamble complained "the great body of the Laws ... exist only in a language which is not the mother tongue of the inhabitants ... of ${ }^{48}$ P. 167. "With the Code Napoléon of 1804, on-going French doctrine relevant to the Coutume de Paris progressively thinned. Cartier's speech to the Assembly and the bill's preamble suggested reduction of chaos was of prime importance."

${ }^{49}$ P. 181. "Despite these last two examples, family law in general, which looked to pre-Revolutionary France for inspiration, continued to qualify the preceding generalisation by rejecting autonomous will in many spheres. There was no divorce, no separation by consent, no adoption; to protect creditors and the families, spouses could not contract with each other; expensive gifts to concubines were prohibited; tutors were appointed by the courts."

${ }^{50} \mathrm{P}$. 157. "As with other aspects of culture, Durham's solution was to anglify the canadiens and thereby 'establish an English population, with English laws and language, in this Province.' Durham hoped to bring about general anglification by political union of the Canadas, with electoral representation based on population, which would in time give Upper Canada many more seats because it would receive the bulk of emigrants from the United Kingdom.” 
British origin." (Greenwood, para.76) The 1846 Codification project contained all the important considerations to help "eliminate judicial chaos and to translate French law, the availability of the French and Louisiana models, and codification as an opportunity to commercialise the law. (Greenwood, para. 74, FN 201)

"Cartier was here being typically sensitive to the interests of the anglophone business community; but it was a measure of simple justice and practicality, considering that about one-quarter of the population did not have French as their mother tongue. The code would be bilingual, as in Louisiana. Despite the views of some later francophone commentators, codification derived almost nothing from 'survivance' concerns. Bi-ethnic political parties, responsible government with its canadienisation of the bench, and the acceptance of commercialisation by francophone politicians combined to diminish radically any real or perceived anglifying threat to the civil law." (Greenwood, para. 76)

\section{Conclusion}

Canada as a nation is still a relatively young and evolving federation of former New France and British North American colonies. As well we have seen reference to the term colony and provincial being interchangeably used in history for a while with the latter prevailing in usage in the last part of the $19^{\text {th }}$ century. As such today we see Canada comprised of ten provinces and three territories, all of whom to varying degrees cam under French control during pre-Confederation and particularly prior to the British final conquest of New France in 1763.

Post 1763 British conquest the French culture, language and heritage did not disappear in the Province of Quebec or in Acadia, along with regions of Ontario and pockets of locations across Canada, including strong Metis Communities in Western and Northern Canada. So the legacy and influence of French culture and norms have lived on and shaped the lives of Canadians across our nation.

In Quebec, the British post-conquest of 1763 soon realized that there were too many French Catholics to assimilate as English-speaking Protestants. For the harmony and continuity of governance, the British implemented the Quebec Act of 1774 which installed a permanent Governor and council, allowed Quebec to retain French civil law in private matters as long as English common law was used in public law matters, and also provided more religious freedom for the Catholic Church, and revoked the requirement to be part of the Church of England to participate in government (Study.com). It also extended the boundaries of Quebec which pre-American revolution caused some further concern for the independent minded US colonies in which war with Britain for independence ensued from 1775-1783 (Study.com).

With the French civil law (on civil matters) preserved and religious freedoms 
provided the French communities and citizens of Quebec were thus enabled to live continuously within a French civil law system which they were traditionally accustomed. While a British common law was imposed for public law matters and given the use of two languages, French and English, within Quebec this bi-jural system soon became complex, but nevertheless provided the tools to protect the French culture, language and civil law of Quebec.

In Acadia, post conquest 1763 the British atop of first expelling the French (Acadians) of the region who would not swear allegiance to the British King, the next settlement thrust of English-speaking settlers loyal to the British. With this came mass numbers of Loyalists fleeing the American War of Independence to the colonies of New Brunswick, Nova Scotia, Cape Breton Island and Prince Edward Island, along with Scottish, Irish and British settlers from Europe. This lead to a point of demographic balance where the British felt comfortable with a sufficiently large base of loyal British subjects that they commenced establishing colonial responsible governments in Acadia (with the exception of Cape Breton Island which in 1784 whilst given colonial status was subjugated to Nova Scotia's watchful eye and administration as Cape Breton was still heavily comprised of troublesome Mi'qMaq, French and Scots. And which they allowed Nova Scotia to re-annex in 1820).

While Canada is federally officially bilingual, within the former colonies of Acadia, only New Brunswick is officially bilingual at the Provincial level. In Acadia, while the British conquest resulted in many geopolitical changes, including shifting territorial boundaries and the movement of thousands of people, it did not supplant the social, cultural, and economic relationships that existed prior to 1763. Many Mi'kmaq, French, and Acadians from Cape Breton (île Royale) rather than swear allegiance archrival Britain, had relocated to southern Newfoundland and Saint-Pierre and Miquelon after the fall of New France. (Morris, p. 88) ) $^{51}$ This relocation arguably helped to further entrench an ongoing kinship between the French, Mi'kmaq, and Acadians of Cape Breton (Île Royale). (Morris, p. 89) For instance, when Mi'kmaq parents without replenishment of parish priests permitted by the British, journey from Cape Breton by sea to Newfoundland and had their children baptised by Catholic priests stationed at Saint-Pierre and Miquelon, records show they often chose French and Acadian godparents who had previous connections to Île Royale. This preference indicates that pre-existing societal customs and connections still factored into decision making in the region for the post-Conquest era.

Clearly, the British conquest didn't sever the ties that these groups have. This prevalence of continued French, Mi'kmaq, and Acadians ties through commercial, cultural, and kinship relations made the British politically paranoid subse-

\footnotetext{
51 “"The French colonies of Saint-Pierre and Miquelon were for the most part populated by French and Acadian individuals who had lived on Île Royale before the Conquest. The French government viewed these individuals as ideal colonists for Saint-Pierre and Miquelon because they were experienced fishermen.”
} 
quent to the Seven Years War, and American War of Independence. From the post conquest period forward, the islands of the St. Lawrence (e.g. Madelaine, Prince Edward Island, Cape Breton, Newfoundland, St Pierre and Miquelon) played a crucial role in maintaining continuity in a close-knit Maritime commercial, cultural, and kinship between the Mi'kmaq, French, and Celts of the region. While these groups have adapted to the realities of the implementation of a new federal order under the imposition of a Canadian Confederation to unite and safeguard the remnants of Britain's North America territory (which Nova Scotia repudiated in its legislature in 1868 by an overwhelming majority and to which Cape Breton is not signatory), for the most part after the Conquest until Confederation in 1867, residents of former Acadia continued to make decisions based on pre-Conquest relationships. (Laidler). Despite British control after 1763, New France's St. Lawrence colonies did not become British and retained their own distinctive cultural mix.

Today Acadia's Mi'kmaq have been gaining growing recognition of their rights federally and within the local courts, and the Acadian communities are gaining language and cultural rights, as well as efforts to preserve the Scots Gaelic language in Cape Breton Island. The later two have civil law tradition as the root of their European heritage and the former have aboriginal traditional laws. It is clearly the markings of a multi-jural legal influence which is blanketed presently by the British common law system which has been imposed post conquest and post Confederation.

Canada's present legal system as we have seen derives from two main European systems (French, then English) along with influences from Louisiana civil code in the shaping of Quebec's civil code, Scottish civil law via heavy Scottish settlement and judicial appointments in early new France, and inherent traditional indigenous law and other sources. From the earliest years of North American discovery and settlement until the defeat of New France in 1763, France employed private law throughout its colonies which was governed by the Custom of Paris imposed by King Louis XIV in 1663 (Laidler). This was the main source of French colonial law, along with ordinances from the Kings and accompanying regulations. Under this system, life and governance is seen as still very feudal, reflecting medieval times with a system of privileges. New France and Acadia during its rule by France did not have their own elected representatives nor assemblies (as the English Colonies did), and they were governed instead by the French Kings' directives, governors and appointed officials.

After the British conquest of 1763, the remnants of New France except for St. Pierre and Miquelon came under British rule and administration. Britain via immigration coming from British Loyalists fleeing the US during and after the US War of Independence, along with the British expulsion and depopulation of French, supplemented with mass clearances and immigration to the Atlantic Provinces (former New France) by Britain of its people from the Scottish and Irish Isles, Britain was able to social re-engineer it's the demographics of the 
former Acadia to shift the balance more favorably to English Speaking Protestants generally more loyal or at least not hostile to the British Crown. This allowed Britain with confidence to stabilize a colonial push for independence it had in recent years experienced and battled against with the United States and elsewhere. Nevertheless with control of Acadia (except what is now Maine) in British hands and with British subjects resident, it was able to implement a system of representative governance and laws in those colonies (exception of Quebec), and the common law system both of which were modeled and transplanted from Great Britain. At this point any traditional French laws which had been practiced in the area roughly in years prior to 1763 became under overwhelming pressures for compliance with a new formal system of law and governance being introduced by the victors, Britain.

Whereas, with Quebec and the looming threat of war by Britain with the United States, Britain was compelled with a limited timeline to reign in control and command of Quebec, and given a large predominantly French population, language, culture and laws, and with assimilation failing, Britain introduced the Quebec Act of 1774 which cleared the way for Quebec to retain its French Civil Laws for private matters, its language and they gained religious freedoms. Thus, civil law survived and operates within Quebec to this day. However, in the rest of New France, I refer to as Acadia, the French culture and language survives and, in many places, thrives but it is within a system of British Common Law that has been imposed. The region is very much distinct from Western Canada, Ontario and Quebec, and New Brunswick has retained and advanced French the furthest within these former colonies. With New Brunswick as an official bi-lingual Province and host a French language law school at the University of New Brunswick, Moncton Campus. As well French language education is available in all these former colonies of New France. In many discernable ways, via culture, language and normative practices traditional French customs has left its indelible legacy on the region.

Considering the social reflections gleaned from the research findings of this study, and to build from a knowledge of the island and regions culture and socio-legal traditions, it is recommended the CBIF perform further research on contemporaneous and current dynamics of Cape Breton's to deepen importance of this review and its future legal and policy applications.

\section{Conflicts of Interest}

The author declares no conflicts of interest regarding the publication of this paper.

\section{References}

Bell, D. G. (1996). Maritime Institutions under the Ancient Regime, 1770-1850. Manitoba Law Journal, 23, 103-131.

Blake Brown, R. Book Review: The Law on Two Islands: A Review of Essays in the Histo- 
ry of Canadian Law, Volume IX: Two Islands: Newfoundland and Prince Edward Island. Dalhousie LJ, 31, 463.

Bourinot, J. G. (1892). Historical and Descriptive Account of the Island of Cape Breton (p. 16). J.W. Foster Brown \& Co.

Cape Breton (2017). https://www.northamericanforts.com/Canada/nscape.html

Caron, C.-I. (2015). The Acadians, the Canadian Historical Association, Immigration and Ethnicity in Canada Series (p. 4). Booklet No. 33. https://www.academia.edu/38774952/The Acadians

Dickinson, J. (1996). New France: Law, Courts, and the Coutume de Paris 1608-1760. Manitoba Law Journal, 23, 32-54.

Elections NB. New Brunswick Election History. https://www.electionsnb.ca/content/enb/en/about-us/history.html

Fabre-Surveyer, E. (1939). The Civil Law in Quebec and Louisiana. Louisiana Law Review, 1, 655. https://digitalcommons.law.lsu.edu/lalrev/vol1/iss4/2

Greenwood, M. (1996). Lower Canada (Quebec): Transformation of Civil Law, from Higher Morality to Autonomous Will, 1774-1866. Manitoba Law Journal, 23, 132-182.

Krause, E. Governors of Isle Royale/Cape Breton, Parks Canada. http://www.krausehouse.ca/krause/FortressOfLouisbourgResearchWeb/Search/Govern orsIsleRCB.html

Laforest, G. (2016). Some Reflections on the Founding of Canada. Federation for the Humanities and Social Sciences, Laval University. https://www.researchgate.net/publication/303204871 Some reflections on the foundi $\underline{\text { ng of Canada }}$

Laidler, P. (2005). The Distinctive Character of the Quebec Legal System (p. 278). Jagiellonian University.

Morris, B. (2012). “Those Two Insignificant Islands": Saint Pierre and Miquelon, and Social Cultural Continuity in Northeastern North America, 1763-1793 (pp. 29-30). University of Saskatchewan.

MyNewBrunswick.com (2021, July 29). Fort Beausejour. Blog. https://mynewbrunswick.ca/fort-beausejour

MyRevolutionaryWar.com. https://www.myrevolutionarywar.com

Ontario Heritage Trust (OHT).

https://www.heritagetrust.on.ca/en/pages/our-stories/exhibits/samuel-de-champlain/hi story/adventures-in-acadia-1604-07

Oxford Reference. Treaty of Aix-la-Chapelle. Oxford University Press. https://www.oxfordreference.com/view/10.1093/oi/authority.20110810104327675

Prince Edward Island (PEI). Legislative Assembly. http://www.gov.pe.ca/paroatom/index.php/prince-edward-island-legislative-assembly

St. Clair, J. (2020, January 1). The Heritage of Inverness County (p. 4). Inverness Oran.

Study.com. The Quebec Act. https://www.Study.com/academy/lesson/the-quebec-act-definition-summary.html

The Fall of New France. Life in Acadia. http://thefallofnewfrance123.weebly.com/life-in-acadia.html

The University of Maine. Explanatory Maps of Saint Croix \& Acadia: Acadian Deportation, Migration, and Resettlement, Canadian-American Centre. https:/umaine.edu/canam/publications/st-croix/acadian-deportation-migration-resettl 


\section{ement}

Vanderlinden, J. (1996). Acadie: À la rencontre de l'histoire du droit avant le derangement. Manitoba Law Journal, 23, 79-102.

Vanderlinden, J. (2019). French Jurisdictional Complexity on the Fringe-Acadia 1667-1710. Law Reviews and Journals, 12, 33.

https://digitalcommons.law.lsu.edu/jcls/vol12/iss1/3

World Heritage Encyclopedia. List of Governors of Acadia.

http://self.gutenberg.org/articles/eng/List of governors of Acadia 